\title{
On the Precipitation of Calcium Carbonate in the Sea by Marine Bacteria, and on the Action of Denitri- fying Bacteria in Tropical and Temperate Seas. \\ By
}

G. Harold Drew.

With Two Figures in the Text.

TABLE OF CONTENTS.

Introduction .

$\therefore 479$

General Considerations and Previous Work . . . . . 480

Description of Apparatus $\quad$. $\quad$. $\quad$. $\quad$. $\quad$. $\quad .484$

Culture Media and Methods _ $\quad$. $\quad$. $\quad . \quad$. 4490

The Investigation of Samples of Sea-water taken off Port Royal, Jamaica $\quad .493$

The Investigation of Samples of Sea-water taken around the Dry Tortugas _ 497

The Investigation of Samples taken from a point 70 miles west of Ushant Island, France

The Investigation of Samples from the Marquesas Keys, Florida, and the Experimental Precipitation of Calcium Carbonate by Bacterial Agency . . . 503

Some Considerations on the Physiography of the Tongue of the Ocean and Andros Island, Bahamas, B.W.I. ․ . . . . 506

Bacterial Investigations in the Deep Water in the Tongue of the Ocean . $\quad . \quad 510$

Hydrographic Observations in the Tongue of the Ocean ․ . . 515

Bacterial Investigation of the Chalky Mud-flats which are being deposited to the

West of Andros Island, Bahamas $\quad . \quad$. $\quad . \quad 519$

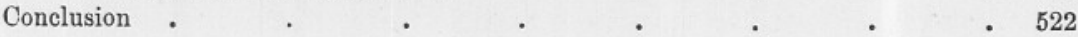

\section{INTRODUCTION.}

THE investigations in the American Tropics described in this paper were made during the summers of 1911 and 1912 under the auspices of the Carnegie Institution of Washington: the work was made possible by the invaluable help and kindness of Dr. Alfred G. Mayer, Director of the Department of Marine Biology. The investigations in Temperate waters were made from the Plymouth Laboratory of the Marine Biological Association of the United Kingdom, and my thanks are due to the Council and Director of the Association for giving me every facility for the work.

Originally the primary object of the investigations was to make a study of the action of marine denitrifying bacteria in Tropical and Temperate seas. The discovery during the course of the experiments that these denitrifying bacteria also possess the power of precipitating Calcium carbonate from soluble Calcium salts present in sea-water has, perhaps, by its geological significance, somewhat overshadowed the interest of the primary object of the work.

NEW SERIES.-VOL, IX. NO. 4. MARCH, 1913. 
The main contentions raised in this paper are-

(1) That in the seas of the American tropics bacteria exist which are actively precipitating Calcium carbonate from the Calcium salts present in solution in sea-water. It is suggested that this bacterial action has been a very considerable factor in the formation of chalk and many other varieties of sedimentary rock, chiefly, or in part, composed of Calcium carbonate. It is also contended that the vast deposits of chalky mud now being formed to the West of the Bahamas, and in the neighbourhood of some of the Florida Keys, are being precipitated by bacterial agency, and that a similar process plays an important part in the cementation of fragments of coral and other detritus into compact coralline rock.

(2) That the destruction of Nitrates by bacterial action in the seas of the American Tropics is far in excess of that occurring in Temperate waters. Hence an explanation is afforded of the relative scarcity of plant life (and consequently of animal life) in Tropical as compared to Temperate seas, in accordance with the terms of Brandt's (2) hypothesis.

Preliminary notes on this work have already been published in the Tortugas Laboratory Reports for 1911 and 1912 (4 and 6) and in the Journal of the Marine Biological Association (5). The chronological sequence of the investigations will be followed in the account given here of the experimental work.

\section{GENERAL CONSIDERATIONS AND PREVIOUS WORK.}

It is generally conceded that the plankton of Tropical and subTropical seas is far less in quantity than that found in colder waters.*

The zoo-plankton depends ultimately for its food on the phytoplankton, hence any factor limiting the growth of the phyto-plankton, which was capable of exercising its influence in Tropical and not in Temperate or Arctic waters, might offer an explanation of this phenomenon. It has been shown by various investigators that this factor is not temperature, light, or salinity, and it has been suggested that the explanation may lie in the relative deficiency in Tropical seas of the Nitrates or nitrogenous compounds which are so essential for all plant life. A matter of common observation in support of this view is the remarkable scarcity of Algal growth in the shallow waters of Tropical shores as compared with that in Temperate regions, and the fact that in the Tropics, wherever sewage or other nitrogenous waste is poured into the sea, a free growth of Algae is found.

* For the most recent work, and full discussion of this subject, see "The Depths of the Ocean," by Murray and Hjort (13), p. 366 et seq., London, 1912. 
At present no really reliable and accurate chemical method of estimating the combined Nitrogen in sea-water exists, hence the above theory cannot be directly put to the test. On the other hand, the existence of denitrifying bacteria in Temperate waters has long been known, and it would seem a fair deduction that should this bacterial destruction of Nitrates take place with greater intensity and completeness in Tropical than Temperate waters, an explanation of the relative scarcity of phyto-plankton in the former would be offered. This suggestion was first made by Brandt (2) in 1901, and is universally known as "Brandt's hypothesis." He enunciated it as follows :-

"If the denitrifying bacteria of the sea, like the closely-investigated denitrifying bacteria of the land, develop a strongly disturbing activity at higher temperatures, only a relatively small production (of phytoplankton) would take place in the warm seas in spite of much more favourable conditions, according to the law of the minimum, owing to the great disturbance amongst the indispensable food substance; whilst, in the cold seas, more nitrogen compounds would be at the disposal of the producers owing to the retardation or suppression of the disturbing process." (From the published English translation.)

The presence of denitrifying bacteria has been demonstrated in Kiel Bay by Baur (1), along the Dutch coast by Gran (9), in the open waters of the North Sea and Baltic by Feitel (7) and Brandt (2 and 3), and in 1909 I identified several of the species described by Gran in samples of water obtained from the Western part of the English Channel. All these denitrifying species have a higher temperature optimum than that of their natural environment, and this is obviously a point strongly in favour of Brandt's hypothesis.

The chief difficulty in the way of putting the hypothesis directly to proof lies in the fact that at present no accurate method of determining the Nitrate contents of sea-water exists, and hence it is impossible to correlate quantitative plankton observations with direct analysis of the amount of combined Nitrogen present in sea-water in different localities. Much valuable work on this subject has been done by Raben (15), but he states that his error in control experiments averages over $30 \%$. An exhaustive study (as yet unpublished) of all the methods of estimating combined Nitrogen in sea-water, as given by various investigators, has been made by Mr. D. J. Matthews, Hydrographer to the Marine Biological Association of the United Kingdom, and he has come to the conclusion that the limits of error in all these methods are so large as to make them quite unreliable. Since chemical methods are at present inadequate to give evidence on 
this hypothetical deficiency of Nitrates in warmer seas, it seemed of interest to investigate the distribution and relative activity of denitrifying bacteria in Tropical waters in comparison to those found in Temperate seas, and it was with this primary object that the present work was undertaken.

The previous researches most closely related to these investigations are those of Gran (9), who isolated a number of species of denitrifying bacteria from the inshore waters of the Dutch coast. He made use of solutions of Nitrates, Nitrites, or Ammonium salts as the sole source of Nitrogen in his culture media, which contained only a dilute solution of Calcium malate as organic nutrient material for the bacteria. $\mathrm{He}$ classifies the bacteria into four groups according to their reactions in pure cultures towards Nitrates or Nitrites :-

(1) Those which reduce Nitrates and Nitrites to free Nitrogen without any Ammonia formation.

(2) Those which readily reduce Nitrates to Nitrites. The Nitrite disappears slowly without perceptible formation of free Nitrogen, and some Ammonia is formed.

(3) Those which cannot reduce Nitrates to Nitrites, but which are capable of slowly removing the Nitrate without perceptible formation of free Nitrogen. Though the Nitrites are not reduced, yet they can serve as the sole source of Nitrogen for the growth of the bacteria.

(4) Those which cannot reduce, and are not capable of assimilating either Nitrates or Nitrites, but will flourish when Ammonium salts are present.

In investigations on samples of water taken in the English Channel some ten miles off Plymouth, I was able to recognize species belonging to the second group of Gran's classification, but could not detect the presence of species belonging to any of the other groups, and it would seem probable that these other groups are chiefly composed of littoral forms.

In fluid culture media inoculated with samples of sea-water and kept at a temperature of $28^{\circ} \mathrm{C}$., Gran found that the formation of Nitrite was detectable in from one to two days, and that eventually all the Nitrate and Nitrite was destroyed in the majority of cases, especially if the cultures were reinoculated at intervals. In my experiments I was able to obtain similar results in cultures kept at $30^{\circ} \mathrm{C}$. after eight days; in cultures kept at $15^{\circ} \mathrm{C}$. the first formation of Nitrite was detectable in from five to six days, but denitrification never proceeded beyond this stage.

Baur (1) showed that the optimum temperature for growth and denitrification of the species described by him lay between $20^{\circ} \mathrm{C}$. and $25^{\circ} \mathrm{C}$., when the bacteria were grown in fluid culture media containing Peptone. 
The most important work on the distribution of marine bacteria is that of Fischer (8) in 1886,1889 , and 1893 , but he does not enter into the chemical activities of the species found, so that the observations do not throw much direct light on problems of the metabolism of the sea. The variations in the number of bacteria found in different surface samples from positions in mid-ocean are somewhat surprising and difficult to account for. Deeper samples were taken by means of a water-bottle made of brass, but in view of the now well-known bactericidal action of metals, and of copper in particular, I do not consider that any great value can be attached to these observations. With the exception of Fischer's work, little seems to have been published on the general distribution of marine bacteria.

A point that has not yet been considered is the origin of the Nitrate supply in the sea. Nitrates are absorbed by diatoms and the phytoplankton in general, and are presumably built up into complex nitrogenous compounds within the plant. If these compounds, on the death of the plant, are broken up and the Nitrogen again rendered available for use in the form of Nitrates, a series of reactions must be gone through which may well be performed by bacterial agency, and this also applies to the waste nitrogenous products of animal metabolism. In addition, it has been shown that Nitrates are actually decomposed by the denitrifying bacteria, which would thus tend to keep the Nitrate concentration down to the level necessary for their own existence, and would come into competition for this essential with other forms of plant life. If the bacteria are successful in decomposing Nitrates to the extent of entirely removing the Nitrogen from all chemical combination, as seems probable from the experiments in cultures, it follows that there must be some source of Nitrates in order that the concentration in the sea may remain constant. The existence of nitrifying bacteria, which are capable of absorbing and combining with the free Nitrogen of the air and eventually giving rise to Nitrates, has been shown by Keding (10) and Keutner (11), but these have so far only been found on the bottom close to shore, or apparently living in symbiosis with algae or plankton organisms. Similarly, Thomsen (16) has demonstrated the presence on the bottom of inshore waters of bacteria which are capable of forming Nitrites from Ammonium salts, and others which can convert Nitrites into Nitrates. It would seem possible that similar bacteria having a nitrifying action remain to be discovered in the open sea.

The precipitation of Calcium carbonate in the sea by bacterial agency is apparently a line of investigation that has not previously been suggested or followed. Both Baur (1) and Gran (9) made use of 
Calcium salts in their culture solutions in order to obviate the great increase in alkalinity that resulted if Potassium or Sodium salts were used, but they have not called attention to, or apparently realized, the probable significance of this precipitation of Calcium carbonate by bacterial agency as an important factor in the formation of various sedimentary calcareous rocks in Tropical seas.

The subject of the precipitation of Calcium carbonate in sea-water has been dealt with by Murray and Irvine (14) in 1889, and again by Murray and Hjort (13) in 1912, and they ascribe the precipitation to the interaction of Ammonium carbonate, derived as an ultimate product of the decomposition of nitrogenous organic matter, with the Calcium sulphate present in sea-water, according to the equation

$\left(\mathrm{NH}_{4}\right)_{2} \mathrm{CO}_{3}+\mathrm{CaSO}_{4}=\mathrm{CaCO}_{3}+\left(\mathrm{NH}_{4}\right)_{2} \mathrm{SO}_{4}$.

Expressed in the terms of the Ionic Hypothesis, this reaction can be explained by the statement that $\mathrm{CaCO}_{3}$ must be precipitated when the product of the concentration of its ions $\mathrm{Ca} \cdot$ and $\mathrm{CO}_{3}^{\prime \prime}$ exceeds a certain limit; an increase in the concentration of $\mathrm{CO}_{3}^{\prime \prime}$ ions is produced by the advent of $\left(\mathrm{NH}_{4}\right)_{2} \mathrm{CO}_{3}$, which is partially ionized into $\mathrm{NH}_{4}$ and $\mathrm{CO}_{3}^{\prime \prime}$, and hence the product of the concentrations of $\mathrm{Ca}$. and $\mathrm{CO}_{3}^{\prime \prime}$ ions is increased, and $\mathrm{CaCO}_{3}$ is thrown out of solution.

Though this reaction has been shown conclusively to occur under experimental conditions, where nitrogenous organic matter has been allowed to putrefy for some time in sea-water, yet it is obvious that its effect must be purely local, and must be confined to the immediate neighbourhood of the decaying organic body, which gives rise to the formation of $\left(\mathrm{NH}_{4}\right)_{2} \mathrm{CO}_{3}$.

In this paper the precipitation of $\mathrm{CaCO}_{3}$ in an unorganized state alone is dealt with. The formation of the calcareous skeletons, tests, and shells of animals, and the skeletons and platelets of algae, which play an immensely important part in the constitution of marine bottom deposits, is beyond the scope of these investigations.

\section{DESCRIPTION OF APPARATUS.}

In 1911 the apparatus at my disposal was of a somewhat primitive nature, as it is difficult when on the first expedition in a new field of work to know beforehand exactly what gear will be necessary. In 1912 a more complete outfit was available, and the Carnegie Institute yacht Anton Dohrn was especially fitted for my requirements.

For deep-sea work the motor trawl winch was modified so as to carry fine sounding wire, and a derrick was rigged aft, projecting over the stern of the boat, over which the wire was led. The motor winch is sunk below the level of the deck, an arrangement which is to be 
greatly commended, as it can be covered over with hatches when not in use, and so affords great economy of deck space, and also has the advantage of bringing the weight of the winch nearer the water-line, and avoiding the unstability that may be caused when a heavy winch is fixed on deck.

The sounding wire was $2.2 \mathrm{~mm}$. in diameter, and consisted of four strands of eight wires each, made of high tensile steel; the breaking strain was given at $400 \mathrm{lbs}$., but in practice I have no hesitation in saying that it far exceeded this figure. The wire was very difficult to kink, and did not show any tendency to untwist or permanently stretch under a tension of about $350 \mathrm{lbs}$; ; it proved in every way satisfactory, and was supplied by Messrs. Bullivant and Co., of London.

For measuring the length of wire run out, one of the fathom measuring sheaves as made by the Telegraph Construction and Maintenance Co., of London, was used. This consisted of a sheave containing a steel wheel about 12 inches in diameter, grooved for and made especially to fit the wire; the length of wire run out is measured by the number of turns of the wheel indicated by a dial on the side of the sheave. The dial has two hands showing fathoms and hundreds of fathoms, the hands revolve backwards on winding in the wire, and so again register zero when the sounding is completed. The axle of the wheel revolves on simple bearings, so the slight inaccuracy unavoidable if ball bearings are employed is prevented.

Samples of the bottom were obtained with one of the "snapper rods," disengaging a $30-\mathrm{lb}$. iron weight on touching the bottom, also supplied by the Telegraph Construction and Maintenance Co. This consisted of two brass jaws closed by a strong spring, and kept apart by a trigger; on touching bottom the trigger was released and the jaws closed on a sample of the bottom; at the same time the $30-1 b$. weight, which was only held in position by the tension of its own weight, was disengaged as soon as the tension was relieved on touching bottom, and so was left behind as the wire was reeled in.

In order to tell the depth at which bottom was sounded, the wire was led through a pulley connected with a spring balance, which thus registered the tension of the wire. On touching the bottom the decrease in tension, due to the release of the weight, was shown on the dial of the balance. This arrangement was not satisfactory in rough weather, as the rolling of the yacht caused such varying tensions on the wire that it was not always possible to tell the exact depth at which the weight was disengaged.

For obtaining samples of water for bacterial analysis a special waterbottle was designed for me by Mr. D. J. Matthews. This apparatus is 
described in detail by Mr. Matthews in the present number of the "Journal of the Marine Biological Association of the United Kingdom," so only a brief account of it will be given here (see p. 525).

The apparatus employed by previous workers for obtaining samples of water from the deep sea for bacteriological examination has either consisted of some sort of water-bottle made of metal, or else of exhausted glass bulbs, with a neck drawn out into a capillary tube, which could be broken off at the depth from which a sample was desired. The use of exhausted glass bulbs presents considerable difficulties for depths as great as 800 fathoms: the bulbs must be strong and very thoroughly annealed, as otherwise the slight shock caused by breaking the capillary neck is liable under the great pressure to make the bulb fly into small fragments: another great disadvantage is the strong probability that the sudden reduction in pressure to which the water is exposed, as it enters the bulb, would immediately kill any bacteria in the water. The employment of a metal water-bottle seemed undesirable in view of the bactericidal action of metals: in order to settle this point some test experiments were made with various metals to see if a suitable one could be found. 100 c.c. of water from the Laboratory tanks at Plymouth, diluted 1 in 100 with sterile sea-water, was exposed for six hours to the action of about two square inches of various metals, with the following results:-

\begin{tabular}{|c|c|c|c|}
\hline Metal. & & $\begin{array}{l}\text { Numbers } \\
\text { of plates. }\end{array}$ & $\begin{array}{l}\text { Number of colonies of bacteria devel- } \\
\text { oping from } 1 \text { c.c. after plating on } \\
\text { Peptone Agar. Counted after } 10 \text { days. }\end{array}$ \\
\hline $\begin{array}{l}\text { Aluminium bronze } \\
\text { Pure copper foil } \\
\text { Brass } " \\
" \\
\text { Pure nickel . } \\
\text { " } \\
\text { Silver (coins) . } \\
\text { " } \\
\text { Control experiment } \\
\text { " }\end{array}$ & $\begin{array}{l}. \\
. \\
. \\
.\end{array}$ & $\begin{array}{l}1 \\
2 \\
3 \\
1 \\
2 \\
3 \\
1 \\
2 \\
3 \\
1 \\
2 \\
3 \\
1 \\
2 \\
3 \\
1 \\
2 \\
3\end{array}$ & $\begin{array}{r}0 \\
0 \\
0 \\
1 \\
0 \\
0 \\
0 \\
0 \\
1 \\
17 \\
12 \\
8 \\
3 \\
2 \\
4 \\
512 \\
560 \\
480\end{array}$ \\
\hline
\end{tabular}


It is thus obvious that none of these metals are suitable for the work, and probably the only metal that could be used would be Platinum, which would be prohibitive on account of the expense.

In order to overcome these difficulties, a water-bottle on a new principle was designed for me by $\mathrm{Mr}$. Matthews.

The container of the bottle consisted of a strong glass cylinder holding about 250 c.c. : this was closed at each end by thick rubber washers, through the centre of which a short piece of thin-walled rubber tubing passed, the tubing being sealed at the end within the cylinder. The washers were fixed in metal plates sliding along the guide bars of the skeleton frame in which the glass cylinder was fixed, and by sending down two messengers along the sounding wire the cylinder could first be opened at both ends and then closed at any required depth. The whole apparatus was first sterilized by steaming in a "Koch," and then the cylinder was completely filled with $95 \%$ Alcohol: the washers were kept tight on the ends of the cylinder by strong springs so that no leakage occurred. When the apparatus had been lowered to the required depth, the first messenger was sent down, this, by hitting a lever, opened the cylinder at both ends, and the alcohol, being of lower specific gravity than sea-water, diffuses out almost instantaneously, causing an upward flow of water through the cylinder. On sending down the second messenger the cylinder, with its sample of water, was tightly closed at each end by the rubber washers.

The washers, with their attached pieces of thin rubber tubing, had sufficient capability of bulging inwards to allow for the contraction of the Alcohol, due to the low temperature at any considerable depth, and to its compressibility being greater than that of sea-water, and similarly the expansion of the sample of water, as the apparatus was hauled up, was compensated for by the partial collapsing of the thin-walled rubber tubing. It is obvious that even had a slight amount of leakage occurred, a leakage inwards during the descent of the apparatus would not vitiate the results, as bacteria would promptly be killed in the $95 \%$ Alcohol, and similarly on hauling up, the leakage, if any, would be outwards, due to the expansion of the sample through the regularly increasing temperature and decreasing pressure, so that the sample would not be contaminated by any of the surface layers through which it was hauled. There was, however, no reason to suppose that any leakage occurred, and it appears that the expansibility of the rubber washers and tubing was sufficient to allow for the small changes in bulk of the fluids within the cylinder. After the first sterilization by steaming, the action of the Alcohol was relied on for sterilization 
between successive samples, and both experimentally and in practice this method was found to be absolutely safe, as all the marine bacteria are very readily killed by Alcohol, and they do not form resistant spores.

After the collection of a sample it was siphoned off into a sterilized glass bottle by means of a sterilized length of rubber tubing: this method was considered preferable to any arrangement of taps leading from the collecting cylinder, owing to the difficulties of cleaning and sterilization which would be involved. Part of the sample was also siphoned off into bottles, which were returned to Plymouth for analysis for salinity: these bottles had previously been thoroughly washed and rinsed with several changes of distilled water, and then dried in an oven; they were closed with rubber stoppers.

It was found in practice that this design of water-bottle worked extremely well and gave very little trouble; it is to be noted that the sample of water collected is kept only in contact with rubber and glass throughout, so that the bactericidal action of metal is avoided.

Surface samples of water were taken in wide-mouthed stoppered bottles, holding about twelve ounces; the samples were always taken from the bows of the boat when moving ahead, in order to avoid any possible contamination from the sides of the boat.

Some samples from depths up to 80 fathoms were collected off the Tortugas in 1911 in retort-shaped glass flasks of about 300 c.c. capacity, with narrow, recurved, long-drawn-out necks. These were sterilized, exhausted, and sealed; they were then lowered in an apparatus in which the extremity of the neck could be broken off at any desired depth by sending a messenger down the sounding wire, when the flasks became completely filled with water. After hauling up, a little water was shaken from the neck, and it was then sealed with the blowpipe. By this method risk of contamination from more superficial layers of water as the apparatus is drawn up is avoided, since the changes in pressure and temperature as it ascends tend to cause a continuous outflow through the narrow neck until the surface is reached.

A somewhat similar apparatus was used for obtaining deep samples from the station 70 miles west of Ushant, but the glass bulbs were smaller, and the tube leading from them was bent at right angles to itself. Considerable difficulty was caused by the breaking of the tube owing to the force of the inrushing stream of water impinging on the wall where it was bent at right angles.

If this form of apparatus is used, all sharp angles in the inlet tube should be avoided, and it should be so arranged that the inrushing 
stream of water spreads itself in a fan-shaped manner over the sides of the bulb, but I do not consider that any form of exhausted glass flask is suitable even for depths as small as 80 fathoms.

In Jamaica no apparatus for obtaining deep samples was available, so the primitive method of lowering a sterilized stoppered bottle with a string tied to the stopper was employed. At the required depth the stopper was pulled out until the bottle was nearly full and then allowed to fall back in place. This method can only be used for very shallow depths owing to the pressure of the water at greater depths making it impossible to withdraw the stopper.

Temperature records were obtained in the Bahamas by means of deep-sea reversing thermometers, specially made by Messrs. Negretti and Zambra, of London. They were tested up to a pressure of three tons to the square inch at the National Physical Laboratory at Teddington, and a table of temperature corrections was furnished for each instrument by the same Institution. These reversing thermometers differ from ordinary thermometers in having a constriction and S-shaped dilatation immediately above the main bulb, and in having a somewhat large secondary bulb at the upper end of the stem. The graduations are reversed, so that the lowest temperature is marked near the top of the capillary portion. On turning the thermometer upside down, the mercury thread breaks at the constriction, and fills the small bulb at the end of the capillary and also part of the capillary itself. The thermometer is read in the reversed position, and when certain corrections have been applied, the reading records the temperature at which the thermometer was reversed. The effect of the pressure of the water is avoided by having the thermometer sealed in an outer glass case. The lower end of this case is partially filled with mercury in which the bulb of the thermometer is immersed, thus allowing for rapid conduction of heat between the mercury in the thermometer bulb and the surrounding water. An auxiliary thermometer was sealed up in the same outer case as the reverser, so that the temperature at which the actual reading was taken could also be recorded. In order to calculate the correction that must be applied to the temperature registered by the reverser, three factors must be known:-

(a) The temperature of the thermometer at the moment of reading.

(b) The kind of glass of which it is made.

(c) The volume, expressed in degrees of the stem, of the secondary bulb and the portion of the stem below the $0^{\circ}$ graduation.

Of these $(a)$ is given by the auxiliary thermometer, and $(b)$ and $(c)$ were engraved on the back of the stem of each reversing thermometer. 
All the thermometers were made of the glass known as Jenaer 16 III, and the apparent dilatation of mercury in this glass is $\frac{\pi}{6300}$. The correction to be applied to the reading of the reverser is given by the formula $\frac{\left(\mathrm{V}^{\circ}+\mathrm{T}\right)(\mathrm{T}-\mathrm{t})}{6300}$, where $\mathrm{T}=$ the temperature registered by the reverser, $\mathrm{t}=$ the temperature shown by the auxiliary thermometer at the moment of reading, and $\mathrm{V}^{\circ}=$ the volume, expressed in degrees of the stem, of the secondary bulb and the portion of the stem below the $0^{\circ}$ mark of the reverser.

The thermometers were mounted in pairs in simple metal cases, and were attached just below the water-bottle. They were suspended in a vertical position by a catch forming part of the water-bottle; this was released by the first messenger, when the thermometers fall by their own weight and reverse; they were hauled up in this reversed position. This simple arrangement proved quite as satisfactory as any of the more complicated reversing frames which are generally in use.

\section{CULTURE MEDIA AND METHODS.}

The culture media employed for isolating and counting the bacteria in plate cultures were the following:-

\section{Peptone Agar.}

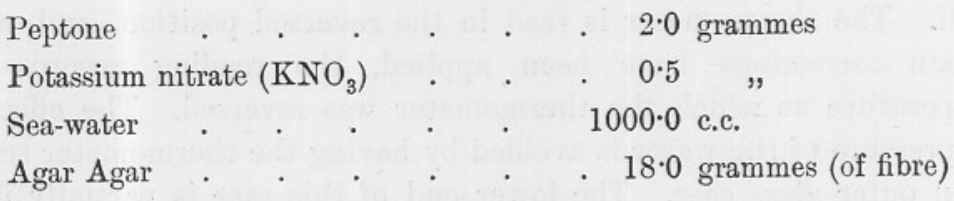

In the earlier work less Agar was used, but eventually it was found more convenient to use a stiffer jelly, and this did not appear to hinder appreciably the growth of the bacteria.

\section{Potassium Malate Agar.}

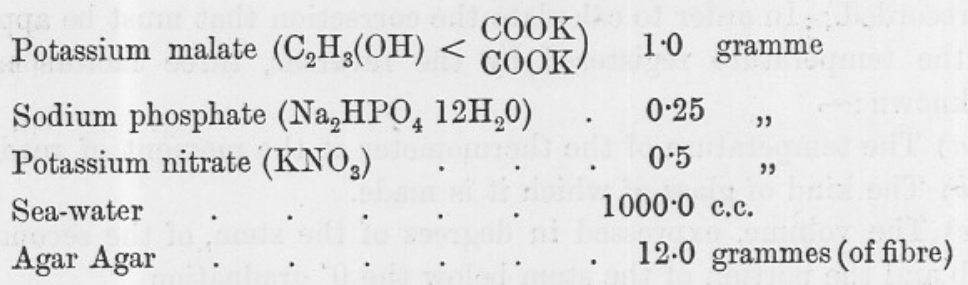

The medium was only filtered through glass wool, so that a very slight floccular precipitate of calcium phosphate was retained. 


\section{Peptone Gelatin.}

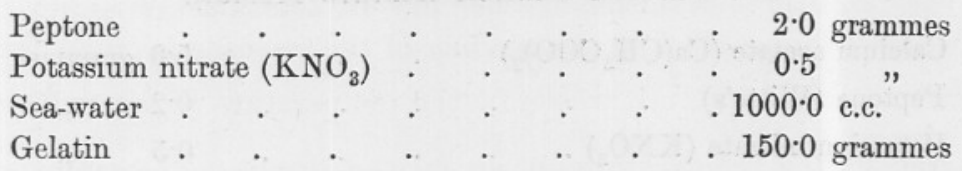

This medium was only used at the Tortugas. It was necessary to keep it cooled with ice to about $20^{\circ} \mathrm{C}$., as the temperature of the Laboratory sometimes rose as high as $37^{\circ} \mathrm{C}$., or even higher, and Gelatin media will not remain solid at these temperatures.

The following fluid media were used:-

\section{Gran's Medium (Modified).}

Potassium nitrate $\left(\mathrm{KNO}_{3}\right)$. $\quad$. $\quad . \quad$. 0.5 gramme

Sodium phosphate $\left(\mathrm{Na}_{2} \mathrm{HPO}_{4}, 12 \mathrm{H}_{2} \mathrm{O}\right)$. . . 0.25 ,

Calcium malate $\left(\mathrm{C}_{2} \mathrm{H}_{3}(\mathrm{OH})<\mathrm{COO}>\mathrm{Ca}\right)$, about . $5 \cdot 0$,

Sea-water . . . . . . . . . 1000.0 c.c.

Calcium malate is only slightly soluble in water, so can be added in excess. Gran used distilled water, and added 30 grammes of Sodium chloride per litre, but in these experiments sea-water has been used instead.

\section{Calcium Succinate Medium.}

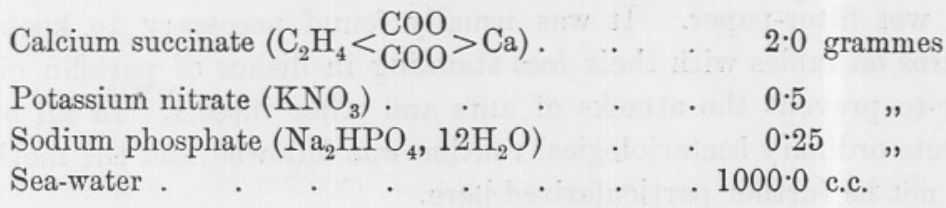

This medium was boiled and filtered before sterilization, to remove the slight precipitate of Calcium phosphate. It was found that this medium with the addition of the phosphate gave a more vigorous growth than if it was omitted.

\section{Calcium Acetate Mediun.}

Calcium acetate $\left(\mathrm{Ca}\left(\mathrm{CH}_{3} \mathrm{COO}\right)_{2}\right)$. $5 \cdot 0$ grammes

Sodium phosphate $\left(\mathrm{Na}_{2} \mathrm{HPO}_{4}, 12 \mathrm{H}_{2} \mathrm{O}\right)$

Potassium nitrate $\left(\mathrm{KNO}_{3}\right)$. $0.25 \quad$,

Sea-water .

$0.5 \quad$,

$1000 \cdot 0$ c.c.

Boiled and filtered before sterilization to remove precipitate of phosphate. 


\section{Peptone Caldium Acetate Medium.}

Calcium acetate $\left(\mathrm{Ca}\left(\mathrm{CH}_{3} \mathrm{COO}\right)_{2}\right)$

Peptone (Witte's)

Potassium nitrate $\left(\mathrm{KNO}_{3}\right)$.

Sea-water .
$5 \cdot 0$ grammes

$0 \cdot 2$

0.5

$1000 \cdot 0$ c.c.

The fluid media II, III, and IV were also made up with the addition of 0.2 grammes of Magnesium tartrate per 1000 c.c.

The fluid media were made up in 1500 c.c. resistance glass flasks, and 1000 c.c. of medium was used for each culture.

For other purposes a simple solution of Peptone in sea-water was employed (2 grammes to 1000 c.c.), and media were also used consisting of this Peptone solution with the addition of $0.5 \%$ of various carbohydrates, such as Cane sugar, Dextrose, Laevulose, Mannite, Lactose, etc., with sufficient Neutral Red solution to colour them, in order to test the acid-forming properties of the bacteria in the presence of Carbohydrates.

The ordinary "Koch" steam sterilizer, and an iron oven for dryheat sterilization, were used, and gasoline cooking stoves were found to be the most satisfactory source of heat. It was found an advantage to use Petri dishes with porous earthenware covers, which enabled the water of condensation to evaporate partially; the evaporation could be checked at any time by covering the dishes with a bell-jar lined with wet filter-paper. It was usually found necessary to keep all cultures on tables with their feet standing in dishes of paraffin oil, in order to prevent the attacks of ants and other insects. 'In all other respects ordinary bacteriological routine was followed, and the methods need not be further particularized here.

The reduction of the Nitrate to a Nitrite in fluid culture media was tested for by the addition of 5 c.c. of $10 \%$ Sulphuric Acid and 2 c.c. of a $1 \%$ solution of Metaphenylene diamine hydrochloride to 25 c.c. of the culture. The production of a brown colouration (due to the formation of Bismarck Brown) is an indication of the presence of a Nitrite, and is an extremely delicate reaction.

The Diphenylamine and Brucine sulphate reactions were also used when testing for the presence of Nitrates.

The formation of Ammonia was tested for by the addition of 5 c.c. of $10 \%$ Potassium hydrate and 5 c.c. of Nessler's Reagent; the white precipitate formed on the addition of the Potassium hydrate does not appreciably interfere with the test, though it renders it less delicate.

Under expeditionary conditions, and in the absence of the somewhat 
elaborate apparatus that would be necessary in order to estimate chemically the amount of denitrification in cultures, it was only possible to compare the rate of denitrification in different cultures by noting the time taken for the first appearance of the Nitrite reaction, and the time taken for all trace of Nitrite or Nitrate to disappear. It seems that the rate of denitrification in culture media inoculated with equal volumes of samples of sea-water must be a function of the number of bacteria in the sample, the temperature at which the cultures are grown, and the specific power of denitrification of the individual species of bacteria. Considering the rapid multiplication of bacteria when the food supply is plentiful, up to a maximum determined chiefly by the accumulation of the waste products of their own metabolism, it appears that the factor of the number of bacteria in the sample may be neglected within the limits of these experiments. For example, the number of bacteria in 1000 c.c. of Gran's medium at the end of twenty-four hours would probably be much the same whether it were inoculated from a sample containing 8 or 16 bacteria per 1 c.c., similarly it was a matter of experience that the first trace of Nitrite formation was observable at about the same time, whether 5 or 10 c.c. of a given sample had been used for inoculation.

Consequently it would appear that for purposes of comparison, and within the limits of the experiments described, if the temperature be the same for the cultures compared, the rate of denitrification is a measure of the specific denitrifying power of the particular species of bacteria.

In the work on the bacterial precipitation of Calcium carbonate, the precipitate, which was often so fine as to tend to remain in suspension, was usually obtained by centrifugalization. It was either preserved in small bottles with some of the culture fluid, or else washed first with distilled water and then with absolute alcohol, and finally allowed to dry. These precipitates were sent to Dr. F. Wright of the Carnegie Geophysical Laboratory at Washington, who with great kindness reported on their mineralogical properties.

\section{THE INVESTIGATION OF SAMPLES OF SEA-WATER TAKEN OFF PORT ROYAL, JAMAICA.}

The work at Port Royal was done in May, 1911, but was of a very preliminary nature. It was necessary to depend on a sailing-boat for obtaining the samples, but owing to the remarkable regularity with which an on-shore wind springs up every morning but little difficulty 
was experienced from this cause. No apparatus for obtaining deep samples was available, but samples were taken from a depth of six fathoms by means of a bottle from which the stopper was pulled by a line, and then allowed to fall back into place. A measurement of the rate of denitrification in fluid culture media inoculated with samples of sea-water was made, but isolation of the bacteria on solid media was not attempted.

The following method was employed:-

Samples of sea-water were collected in sterilized stoppered bottles from the surface, and from depths of 3 and 6 fathoms, from positions about five miles from shore, where, from a consideration of the wind and tide, the water was probably under truly oceanic conditions and unaffected by the neighbouring land.

10 c.c. of these samples were added to 1000 c.c. of Gran's medium. The cultures were kept in a moderate light, and the temperature varied from $25^{\circ}$ to $31.5^{\circ} \mathrm{C}$. The average temperature during the growth of each culture was noted.

In a typical culture made from surface water, and for which the average temperature was $29^{\circ} \mathrm{C}$., the first indication of the formation of a Nitrite, as given by the Metaphenylene diamine reaction appeared after 27 hours; after 38 hours the brown colour produced in this reaction was very intense, the culture became cloudy, and on testing with Nessler's Reagent slight Ammonia formation was apparent. After 48 hours the culture became very cloudy and a scum of bacterial growth developed: the Nitrite and Ammonia reactions remained unaltered. After 63 hours the Nitrite reaction was somewhat less marked, the Ammonia reaction was unaltered, and bubbles of gas began to appear. After 72 hours many bubbles of gas were being produced, and the Nitrite and Ammonia reactions were very slight. After 86 hours the bubbling had ceased, and no Nitrite or Ammonia was present in the culture. Testing the culture for Nitrates by the Brucine and Diphenylamine reactions then showed that no Nitrate was left in the solution.

In the absence of a gas analysis apparatus the nature of the gas evolved could not be determined, but considering that it was noninflammable, did not turn lime water milky, and that the Nitrate originally present had been destroyed, it seems strongly probable that this gas was pure Nitrogen. Thus in 86 hours 0.5 gramme of Potassium nitrate had been decomposed by bacterial growth. If a further 0.5 gramme of Potassium nitrate were then added, it was rapidly decomposed, and this could be repeated many times until the other constituents of the culture medium were used up, or the 
accumulation of the products of metabolism had become toxic to the bacteria.

It was found that the rate of denitrification varied with the temperature, and that in cultures kept at a temperature of between $10^{\circ}$ and $12^{\circ} \mathrm{C}$. no growth or denitrification occurred. The denitrification was always more rapid in cultures from water taken from a depth of 3 or 6 fathoms than from the surface. It was also more rapid with samples taken from the thick muddy water of a mangrove swamp, where organic matter was plentiful.

The bacteria present in the cultures were very minute, actively motile bacilli with rounded ends.

An abstract of the behaviour of a few of the cultures is given below.

1. Sample collected 5 miles S. of Port Royal, wind S.E., force 4, tide rising. Sample taken from surface. 1000 c.c. of Gran's medium was inoculated with 10 c.c. of sample.

After 20 hours a slight cloud developed in the culture, and faint Nitrite reaction was given.

After 36 hours a dense cloud developed in the culture, and strong Nitrite reaction was given.

After 60 hours a dense cloud and scum developed in the culture, and strong Nitrite and faint Ammonia reaction was given.

After 70 hours a dense cloud, scum, and bubbles developed in the culture, and faint Nitrite and faint Ammonia reaction was given.

After 84 hours culture was less cloudy, with much scum, no Nitrite or Nitrate reaction, very faint Ammonia.

The average temperature at which the culture was grown was $30^{\circ} \mathrm{C}$.

2. Sample collected from same spot under similar conditions, from a depth of 3 fathoms. 1000 c.c. Gran's medium was inoculated with 10 c.c. of sample.

After 20 hours a slight cloud developed in the culture and faint Nitrite reaction was given.

After 27 hours a denser cloud developed in the culture and strong Nitrite and faint Ammonia reaction was given.

After 38 hours a dense cloud and scum developed in the culture and strong Nitrite and faint Ammonia reaction was given.

After 48 hours a dense cloud and scum developed in the culture and moderate Nitrite and faint Ammonia reaction was given.

After 63 hours a moderate cloud, thick scum, and bubbles developed in the culture and faint Ammonia reaction was given.

NEW SERIES,-VOL. IX. NO. 4. MARCH, 1913. 
After 72 hours a slight cloud and thick scum, no Nitrite or Nitrate, and very faint Ammonia reaction.

The average temperature at which the culture was grown was $29^{\circ} \mathrm{C}$.

3. Sample collected from a spot 6 miles S. of Port Royal, wind E.S.E., force 4, high tide (slack). Taken from surface. 1000 c.c. Gran's medium was inoculated with 10 c.c. of the sample.

After 20 hours a slight cloud developed in the culture; no Nitrite reaction was given.

After 27 hours a slight cloud developed in the culture; faint Nitrite reaction was given.

After 38 hours a dense cloud developed in the culture; strong Nitrite and faint Ammonia reaction was given.

After 48 hours a dense cloud and scum developed in the culture; strong Nitrite and faint Ammonia reaction was given.

After 63 hours a dense cloud and scum developed in the culture; moderate Nitrite and faint Ammonia reaction was given.

After 72 hours a moderate cloud, scum, and bubbles developed in the culture; very slight Nitrite and faint Ammonia reaction was given.

After 86 hours a moderate cloud and scum, no Nitrite or Nitrate and very faint Ammonia reaction.

The average temperature at which the culture was grown was $29^{\circ} \mathrm{C}$.

4. Sample taken from surface water of the large mangrove swamp lying N.W. of Port Henderson. 1000 c.c. of Gran's medium inoculated with 10 c.c. of sample.

After 20 hours no cloud or Nitrite reaction.

After 24 hours slight cloud and slight Nitrite reaction.

After 40 hours strong cloud and scum, strong Nitrite and slight Ammonia reaction.

After 75 hours cloud, scum, and bubbles, no Nitrite or Nitrate and slight Ammonia reaction.

The average temperature at which the culture was kept was $30^{\circ} \mathrm{C}$.

5. Subculture from Culture (1). 1000 c.c. Gran's medium inoculated with 5 c.c. of culture (1) and kept at a temperature of $10^{\circ} \mathrm{C}$. to $12 \mathrm{C}$. by means of ice.

After 100 hours the culture was quite clear, and gave no Nitrite reaction. It was then removed from the ice and kept at the room temperature, which averaged $30^{\circ} \mathrm{C}$.

After 107 hours a dense cloud developed in the culture, and strong Nitrite and faint Ammonia reactions were given. 
After 120 hours a dense cloud, scum, and bubbles developed in the culture, and moderate Nitrite and faint Ammonia reactions were given.

After 131 hours a faint cloud, scum, and bubbles developed in the culture, and very faint Nitrite and faint Ammonia reactions were given.

After 146 hours a faint cloud and scum, no Nitrite or Nitrate, and very slight Ammonia reactions were given.

Twenty cultures from samples of water taken well out to sea from Port Royal were made, and the process of denitrification followed through with each. All gave very similar and consistent results, but the rate of denitrification decreased rapidly with the temperature at which the cultures were grown: thus at an average temperature of $27^{\circ}$ C. the first trace of the Nitrite reaction appeared after about 40 hours, and denitrification was complete after about 100 hours.

The results of precisely similar experiments that I made with samples of water taken from the English Channel near Plymouth in the autumn of 1909 , showed that there the process of denitrification was very much slower, and was never complete at the room temperature $\left(17^{\circ} \mathrm{C}\right.$.). The first trace of the formation of a Nitrite in cultures in the modified Gran's medium, as detected by the Metaphenylene diamine reaction, occurred about the fifth day, and a large proportion of the Nitrite and Nitrate always remained, even in the oldest cultures. In similar cultures incubated at $30^{\circ} \mathrm{C}$. denitrification was complete by the eighth day at earliest, but uniformly consistent results were not obtained, as in some of the cultures complete denitrification never occurred, even after several months.

It would thus appear that even under similar temperature conditions, the marine bacteria in the seas off Jamaica are much more active in causing denitrification than those found in the English Channel, and since the rate of denitrification is a function of the temperature, it follows all the more that the destruction of Nitrates by bacterial agency in the seas round Jamaica must be far in excess of that occurring in the cooler waters of the English Channel.

\section{THE INVESTIGATION OF SAMPLES OF SEA-WATER TAKEN AROUND THE DRY TORTUGAS.}

The Dry Tortugas consist of a group of eight small Keys, the largest of which, Loggerhead Key, is only about $\frac{3}{4}$ mile long by $\frac{1}{8}$ th wide. They are situated about 150 miles from the mainland of Florida, and form the extreme western end of the chain of the Florida Keys. The 100 -fathom line lies some 30 miles to the S. and S.W. of the 
Islands and then trends round in a N.W. direction; beyond the 100 -fathom line the depth increases with moderate rapidity until depths of from 1000 to 1400 fathoms are reached. To the E., N.E., and N., as far as the coast of Florida, the water is shallow, the soundings showing from 20 to 30 fathoms in most places. Beyond the 100 -fathom line to the southward the influence of the Gulf Stream begins to make itself felt, though the region of maximum current velocity here lies nearer the coast of Cuba. The Tortugas Keys are of purely coral formation; they consist entirely of broken shell and coral sand, and no soil is present; the greatest elevations are the hurricane ridges, which are not more than 15 feet above sealevel, and during a hurricane the islands are sometimes completely submerged. There is no vegetation on the smaller Keys, but Loggerhead Key, on which the Carnegie Laboratory is situated, is partially covered with a growth of bushes and coarse grass. There is no freshwater supply on the islands.

From these considerations it is obvious that the risk of contamination of samples of sea-water, taken a few miles from the Keys, through land bacteria is very small, and that such samples may be taken as being truly oceanic.

The motor-yacht Anton Dohrn, and smaller motor-boats, made the collection of samples an easy matter, and the well-equipped Laboratory made possible fuller investigations than those attempted in Jamaica.

A number of cultures were made in Gran's medium under conditions exactly comparable to those made at Port Royal, and the rate at which the process of denitrification proceeded was observed. The results agreed almost exactly with those obtained at Port Royal, so need not be described in detail. It thus seems that the denitrifying power of the bacteria in the seas around the Tortugas is the same as that of those around Jamaica.

Cultures were also made on various solid media, and pure cultures of the various species of bacteria were isolated by plating in Petri dishes with Peptone Agar. Samples of surface water taken from various positions round Tortugas as far as possible removed from influence of the land, and collected on sunny days, gave an average count of 14 colonies per 1 c.c. of sample. Counts of several plates from the same locality, and from different localities, showed a somewhat remarkable agreement as to the number of colonies present, the highest count ever obtained being 20 and the lowest 8 per 1 c.c. Allowing for experimental error, this shows great uniformity in the distribution of bacteria in the sea round Tortugas. 
The colonies appeared to be of two kinds when grown on Peptone Agar, one much more plentiful than the other. Subcultures made from these colonies in Gran's medium showed that the bacteria forming the most common type of colony produced an active denitrification, while the others grew very slowly in this medium and produced no denitrification.

The characteristics of the denitrifying form are as follows :-

The bacterium is a very minute, actively motile short rod, with rounded ends, readily giving rise to involution forms in old cultures.

On the Potassium malate, or Peptone Agar media, colonies are visible as minute white specks after 6 to 8 hours, when the room temperature averages $29.5^{\circ}$ C. After about 18 hours the colonies are well developed; they are white in colour, circular, but with a finely irregular outline, and have a granular appearance. Superficial colonies are much elevated at first, but as growth proceeds spread rapidly over the surface of the Agar. Deep colonies remain small, circular, and discrete.

Growth is somewhat more rapid on Peptone Agar than on the Potassium malate Agar, and the older colonies develop a brownish tinge in the centre when growing on the former medium. On Gelatin Peptone $(5 \%$ Peptone in sea-water and kept at between $20^{\circ}$ and $25^{\circ} \mathrm{C}$. to ensure the medium remaining solid) growth was very slow : in stab cultures growth proceeded slowly from the surface downwards, leaving a funnel-shaped depression of liquefied Gelatin.

Acid formation, as shown by the Neutral Red reaction, occurs in Dextrose, Laevulose, Mannite, and Cane Sugar, but not in Lactose media.

Growth is inhibited at a temperature of $10^{\circ}$ C., but takes place slowly at $15^{\circ} \mathrm{C}$.

Growth is much retarded by exposure to bright sunlight, but the bacteria are not killed by a ten hours' exposure.

The bacteria are facultative anaërobes, but growth under anaërobic conditions is very slow.

In Gran's medium growth is rapid, but no growth occurs if the Potassium nitrate be omitted, or if the Calcium malate be replaced by Calcium carbonate. Growth in a pure solution of Peptone in seawater is slight, but becomes abundant if Potassium nitrate be added, when denitrification quickly ensues. The most rapid early growth was produced in sea-water containing $2 \%$ Peptone, $1 \%$ Potassium malate, and $0.5 \%$ Potassium nitrate, and in this clear medium a slight floccular precipitate, presumably of Calcium salts derived from the sea-water, was soon formed. Growth was also rapid at first in a solution of $5 \%$ Potas- 
sium malate and $0.5 \%$ Potassium nitrate in sea-water, but in this medium growth apparently ceased after a few days and denitrification was never complete; a slight precipitation occurred, and the solution was found to have very definitely increased in alkalinity.

This bacterium does not appear to have been previously described, and I propose for it the name of "Bacterium calcis," owing to its power of precipitating Calcium carbonate from solutions of Calcium salts. This point will be dealt with later in the paper.

The characteristics of the scarcer non-denitrifying form of bacterium found on the Agar plates are as follows :-

The morphological characters are exactly similar to those of B. calcis.

Growth on the Potassium malate Agar medium is very slow and indefinite. On Peptone Agar growth is somewhat slower than in the case of the $B$. calcis. On the surface, circular cream-coloured colonies are formed, having a brownish centre, the edges are smooth and regular, and the colony remains discrete and does not tend to spread. The deep colonies are smaller and usually ovoid in shape, and of a somewhat darker colour than those on the surface.

No growth was obtained on Gelatin media.

Acid formation, as shown by the Neutral Red reaction, occurs in Dextrose and Laevulose, but not in Cane Sugar, Lactose, or Mannite media.

Growth takes place slowly at $10^{\circ} \mathrm{C}$. No visible growth occurred at $0^{\circ} \mathrm{C}$., but cultures were not killed by twenty-four hours' exposure to this temperature.

Growth is retarded by light, and cultures are killed by four hours' exposure to bright sunlight.

The bacterium is a strict aërobe.

Free growth takes place in Gran's medium, but develops much slower than in the case of the denitrifying form: no growth occurs if the Potassium nitrate be omitted entirely, but takes place freely if a mere trace in excess of that normally present in the sea-water be added, though no denitrification results. Attempts were made to discover whether this bacterium had any nitrifying or denitrifying action in various culture media, but uniformly negative results were obtained. Nitrites were neither oxidized to Nitrates, nor reduced to Ammonia or free Nitrogen, and Ammonia salts were unaffected. No growth was obtained in any culture medium that did not contain at least a trace of Nitrates, so it was not practicable to ascertain whether the bacterium had a nitrifying action without the necessary facilities for quantitative work.

On one occasion samples were obtained from various depths up to 
90 fathoms at a point near the Gulf Stream region, 25 miles south of Tortugas. Exhausted glass flasks, with capillary necks which could be broken off at the required depth, were used for the purpose.

These samples were plated in the Peptone Agar medium and counted with the following average results :-

\begin{tabular}{r|r|r|c}
\hline Depth in fathoms. & $\begin{array}{c}\text { Denitrifying } \\
\text { forms. } \\
\text { (Bacterium calcis.) }\end{array}$ & $\begin{array}{c}\text { Non-denitrifying } \\
\text { forms. }\end{array}$ & $\begin{array}{c}\text { Number of Colonies } \\
\text { developing from 1 c.c. } \\
\text { of sample. }\end{array}$ \\
\hline 0 & 9 & 2 & 11 \\
10 & 25 & 4 & 29 \\
40 & 2 & 2 & 4 \\
60 & 5 & 3 & 8 \\
90 & 5 & 6 & 11 \\
\hline
\end{tabular}

It is probable that these figures are not very reliable, especially for the greater depths, since it is possible that many of the bacteria were killed by the sudden reduction of pressure to which they were exposed as the water entered the exhausted bulb.

\section{THE INVESTIGATION OF SAMPLES TAKEN FROM A POINT}

\section{MILES WEST OF USHANT ISLAND, FRANCE.}

This spot was chosen as it is sufficiently far out in the Atlantic to be largely out of the influence of the English Channel water. The object was to investigate truly oceanic bacteria, and previous work in 1909 had shown that the bacterial flora of the Channel water was relatively very complicated, probably owing to the presence of littoral forms. The Marine Biological Association of the United Kingdom very kindly sent their s.s. Oithona from Plymouth for this work, and gave me every facility both on board and in their Laboratory. As in Tortugas, the deep samples were collected in exhausted glass flasks, and accordingly, as previously explained, the results obtained from the deep samples cannot be considered to possess any very great degree of accuracy.

Attempts were made to plate the samples in Peptone Agar on board the boat, but the result was not satisfactory, as owing to the motion of the boat the jelly set in irregular waves and lumps. Consequently the samples were kept on ice, and cultures were made from them at Plymouth 24 hours after collection. It is clear that if in the future 
attempts are made to make plate cultures on board a small boat in rough weather, a very delicately swung table will be necessary, or else the roll-tube culture method must be employed.

Three plates on Peptone Agar were made from each sample, 1 c.c. of the sample being used for each plate. The plates were kept at the room temperature, averaging about $20^{\circ} \mathrm{C}$., and the colonies were well developed after 48 hours: they appeared to be all of one kind. A count gave the following results :-

\begin{tabular}{|c|c|c|c|c|c|c|c|c|}
\hline \multicolumn{2}{|c|}{ Depth in fathoms. } & & & & & \multicolumn{3}{|c|}{$\begin{array}{l}\text { Number of colonies } \\
\text { from } 1 \text { c.c. of sa }\end{array}$} \\
\hline 0 & $\ldots$ & $\ldots$ & $\cdots$ & $\ldots$ & $\cdots$ & $\cdots$ & $\ldots$ & 7 \\
\hline 10 & $\ldots$ & $\ldots$ & $\ldots$ & $\cdots$ & $\cdots$ & $\cdots$ & $\ldots$ & 9 \\
\hline 20 & $\cdots$ & $\ldots$ & $\cdots$ & $\ldots$ & $\ldots$ & $\ldots$ & $\ldots$ & 6 \\
\hline 30 & $\ldots$ & $\ldots$ & $\ldots$ & $\ldots$ & $\ldots$ & $\ldots$ & $\ldots$ & 5 \\
\hline 50 & $\ldots$ & $\ldots$ & $\ldots$ & $\ldots$ & $\ldots$ & $\ldots$ & $\ldots$ & 6 \\
\hline 70 & $\ldots$ & $\ldots$ & $\ldots$ & $\ldots$ & $\ldots$ & $\ldots$ & $\ldots$ & 30 \\
\hline 80 & $\ldots$ & $\ldots$ & ... & $\ldots$ & $\ldots$ & $\ldots$ & $\ldots$ & 20 \\
\hline
\end{tabular}

The increase in the number of colonies at 70 and 80 fathoms is somewhat remarkable, but no conclusions in this respect can be drawn from one series of observations.

The characteristics of this bacterium are as follows :-

Morphologically it resembles the $B$. calcis already described.

On Peptone Agar after about 36 hours at $20^{\circ} \mathrm{C}$., the colonies are white in colour, circular, with a finely serrated outline and a coarsely granular appearance. Superficial colonies grow very rapidly, and may spread as a whitish semi-transparent growth of irregular shape over the surface of the Agar. The deep colonies remain small, globular, and discrete. In old Agar cultures a brownish tinge is developed, and the colour may diffuse through the substance of the Agar. On Gelatin Peptone growth was rapid: in stab cultures growth proceeded from the surface downwards, leaving a funnel-shaped depression of liquefied Gelatin, and eventually all the Gelatin became liquefied.

Acid formation, as shown by the Neutral Red reaction, took place in Dextrose, Mannite, and Laevulose, but not in Cane Sugar or Lactose media.

1000 c.c. of Gran's medium, inoculated on board with 10 c.c. of a surface sample immediately after collection, and kept at an average temperature of about $20^{\circ} \mathrm{C}$., showed the first trace of Nitrite formation after 70 hours. After 84 hours a very strong Nitrate 
reaction was obtained, and a slight Ammonia reaction was given with Nessler's reagent. The process of denitrification, even after the lapse of weeks, did not extend beyond this, and no bubbles of gas were formed. Other experiments made with subcultures from Agar and Gelatin media gave similar results, so that it appears that this bacterium cannot entirely break down Nitrates at a temperature of $20^{\circ} \mathrm{C}$. The optimum ternperature for denitrification produced by this bacterium appears to be about $20^{\circ} \mathrm{C}$., as the process was less rapid at average temperatures of $17^{\circ} \mathrm{C}$. and $25^{\circ} \mathrm{C}$. At a temperature of $32^{\circ} \mathrm{C}$. rapid growth took place, but no denitrification resulted.

It should be noted that these temperature observations were only made with subcultures from colonies on Peptone Agar and Peptone Gelatin media, and it is possible that the power of denitrification becomes diminished after cultivation on such media. Further and more accurate temperature experiments are required in which the culture medium is directly inoculated with freshly collected samples of water.

This bacterium appears to be closely related to the Bacterium calcis, its chief points of difference being-

1. Lesser denitrifying power and lower temperature optimum for denitrification.

2. More rapid growth on Gelatin media.

3. Absence of acid formation in media containing Cane Sugar.

INVESTIGATION OF SAMPLES OF WATER FROM THE MARQUESAS KEYS AND THE EXPERIMENTAL PRECIPITATION OF CALCIUM CARBONATE BY BACTERIAL AGENCY.

The Marquesas Keys constitute a coral atoll which forms part of the long chain of Keys separating the Gulf of Mexico from the Straits of Florida. Within the atoll the water is very shallow, and the bottom consists of a fine chalky mud many feet deep. Samples of the water from within the atoll were sent to me at Plymouth by post, and examined fourteen days after collection.

On plating on Peptone Agar, an average of 800 colonies per 1 c.c. of the sample were obtained. These colonies appeared to be all of one species, and in appearance and all cultural characteristics were identical with the Bacterium calcis previously described as occurring around the Tortugas.

A suspension of these bacteria from a culture on Peptone Agar was 
made in sterile sea-water, and a similar suspension containing roughly the same number of bacteria was made from a third subculture on Peptone Agar of the bacteria obtained from the station 70 miles west of Ushant. 1 c.c. of each of these suspensions was then added to 1000 c.c. of the modified Gran's medium: some of these cultures were kept at an average temperature of $20^{\circ} \mathrm{C}$. and others at $32^{\circ} \mathrm{C}$., with the following results :-

At $20^{\circ}$ C. cultures from Marquesas showed trace of Nitrite after 45 hours.

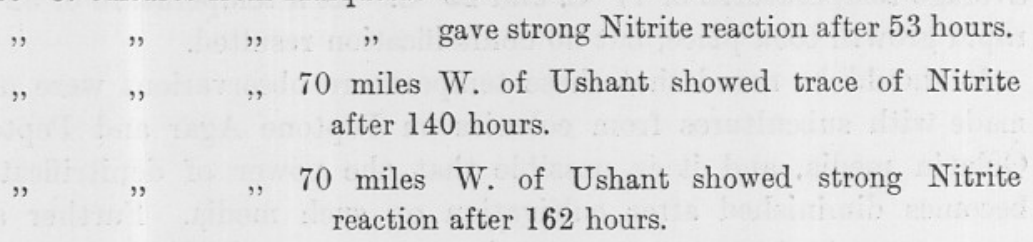

In both cases a slight amount of Ammonia was recognizable by Nessler's reagent when the Nitrite reaction was strong, but decomposition of the Nitrite did not proceed further, even after 14 days.

At $32^{\circ}$ C. cultures from the Marquesas showed trace of Nitrite after 18 hours.

$, \quad, \quad, \quad, \quad$, $\quad 70$ miles W. of Ushant never gave Nitrite or
hours.
Ammonia reaction.

The culture from the Marquesas showed a slight amount of Ammonia formation, but the decomposition of the Nitrite did not proceed further.

From these experiments it appears that the bacteria from subcultures from the Marquesas have a much greater denitrifying power than those from subcultures from a point 70 miles west of Ushant, and that as the bacteria from the Marquesas appear to be of the same species as those investigated at the Dry Tortugas, their power of causing complete denitrification in Gran's medium has been lost by successive cultivations on Peptone Agar.

The presence of the thick layers of fine chalky mud within the Marquesas Keys, and elsewhere in many places near the Florida coast, led to a consideration of the possibility of its precipitation by bacterial agency.

Since these bacteria grow freely in Gran's medium, the Calcium salt of a simple organic acid is a sufficient source of organic food for them, and it seems probable that they would thrive in sea-water containing 
the products of decomposing vegetable matter, provided that the Nitrate supply, and conditions of light and temperature, were suitable. Such conditions should be especially well fulfilled by the drainage into the sea of a well-wooded country with a calcareous subsoil, and the soluble organic calcium salts would be precipitated as Calcium carbonate by the action of the bacteria. In addition, the elimination of the acid radical from the Nitrate in the process of denitrification, by whatever stages it may occur, must leave the alkaline base free to destroy the normal equilibrium of the salts in sea-water, and by increasing the alkalinity, would also result in the precipitation of Calcium carbonate.

To test this theory cultures were made in a medium having the following composition :-

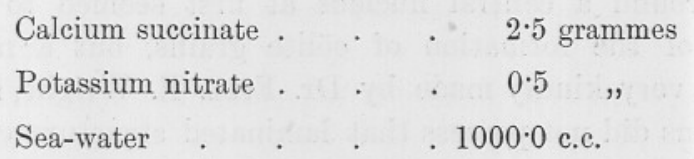

Calcium succinate is soluble in these proportions, and the medium is quite clear. Free growth was manifested by the cloudiness of the medium 48 hours after inoculation, and Nitrite formation was apparent.

After 96 hours the medium appeared quite milky, and this milkiness was due to the presence of exceedingly fine particles of a substance which was soluble in dilute Hydrochloric Acid with evolution of gas, and was presumably Calcium carbonate. In some cultures these particles settled as a definite sediment, but in others the particles were so minute that they showed little tendency to settle, and could only be separated by centrifugalization. The conditions determining the size of the particles formed could not be ascertained, as the size varied in cultures which were apparently made and grown under identical conditions.

The addition to cultures in which the particles of Calcium carbonate were so small as to remain in suspension of any foreign substance, such as finely powdered Calcium sulphate, or of larger particles of sand, resulted in the aggregation around them of the particles of Calcium carbonate, forming a concretion around a central nucleus. These concretions were hard and of almost crystalline appearance under the microscope, and were soluble in dilute Hydrochloric Acid with evolution of bubbles of a gas which, when the operation was performed on a microscopic slide, could be completely absorbed by running in a solution of Sodium hydrate under the cover-slip. Once this process of concretion had been initiated, it 
appears to progress independently of the presence of particles which act as nuclei, and a large concretion may often be found having a number of smaller concretions around it, or continued into a chain of small spheres, the whole presenting somewhat the arrangement shown by freely budding yeast cells. The deposition of this form of Calcium carbonate also takes place on the sides of the flask, and more especially over any area where the glass is scratched or roughened.

From these results it would seem strongly probable that the layers of fine unorganized chalky mud found in the Marquesas Keys are being precipitated by the action of the Bacterium calcis, and it would seem a reasonable suggestion that similar bacterial action may have played an important part in the formation of chalk and other limestone formations in geologic times. The formation of semi-crystalline concretions round a central nucleus at first seemed to suggest an explanation of the formation of oölite grains, but a mineralogical examination, very kindly made by Dr. Fred. E. Wright, showed that the concretions did not possess that laminated structure characteristic of oölite grains, and that their crystalline structure was nearer that of Calcite than Aragonite.

\section{SOME CONSIDERATIONS ON THE PHYSIOGRAPHY OF THE TONGUE OF THE OCEAN AND ANDROS ISLAND, BAHAMAS, B.W.I.}

The position of the Tongue of the Ocean is shown in the map on page 507, which includes the greater part of the Bahama group, and shows its position relative to Florida and Cuba. The Tongue consists of a long and narrow stretch of deep water, running in a N.N.W.-S.S.E. direction, and except at its northern end it is completely surrounded by shallows or by land. On the west, for about three-quarters of its length, it is bounded by the coast of Andros Island; south of Andros it is separated from the Santaren Channel by some 60 miles of shallow water lying over the Great Bahama Bank. To the south it is separated from the Old Bahama Channel by over 50 miles of shallows, averaging not more than 3 fathoms in depth. To the east it is separated from the deep water of Exuma Sound by from 20 to 40 miles of shallow water of from 2 to 3 fathoms in depth, and by the chain of islands and cays extending in a N.N.W. direction from Great Exuma Island. The mouth of the Tongue of the Ocean lies between New Providence Island on the east and the northern extremity of Andros Island on the west; it is here some 25 miles wide, and it maintains this width for the greater part of its length 
as it stretches south. Between the southern extremity of Andros and Green Cay it narrows to under 20 miles, but south of this point it expands eastwards into an almost circular terminal basin of about 35 miles diameter. The total length is about 120 miles.

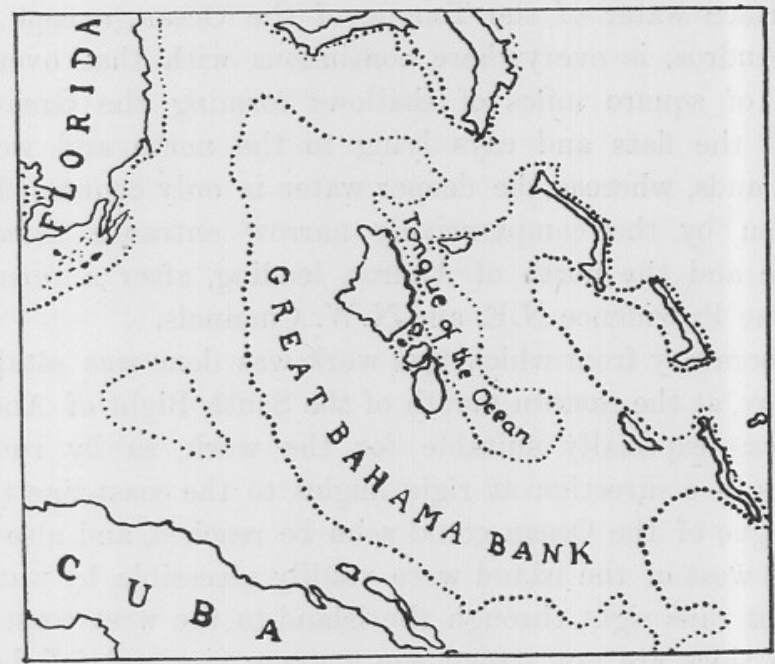

FIG. 1.-Map showing position of the Tongue of the Ocean. The dotted line shows the 100 -fathom line; in most parts this almost coincides with the 5 -fathom line.

To the north, the Tongue is connected by a stretch of deep water extending in a N.E. direction, with the Providence N.E. Channel, and the Providence N.W. Channel, leading respectively into the Atlantic and the Straits of Florida, and thus the Tongue of the Ocean is brought into direct connection with the two main divisions of the Gulf Stream.

The soundings in this area show a slight but regular upward gradient from a depth of 1084 fathoms at the mouth, to 740 fathoms in the southern terminal basin. Along the margins the gradient is extremely steep, and along the coast of Andros our observations showed that it was almost perpendicular at a distance of from a quarter to half a mile from the shore, but unfortunately no complete observations have been made from which this gradient could be calculated. When attempting to make soundings in this area, the sinker (a 30-lb. conical iron weight) in every case was caught upon what was probably some projection on a submarine cliff, and it was impossible to free it; after several such attempts and loss of sinkers the soundings were abandoned. The entrance to the Tongue by the Providence N.E. 
Channel is of steadily increasing depth, up to 2200 fathoms at its junction with the still deeper water of the Atlantic; the Providence N.W. Channel becomes shallower at its junction with the Straits of Florida, and between Great Isaac and the western end of Bahama Island is only between 200 and 300 fathoms in depth.

The surface water of the Tongue of the Ocean, except along the coast of Andros, is everywhere continuous with that overlying the thousands of square miles of shallows forming the Great Bahama Bank, and the flats and cays lying to the north and west of the Exuma Islands, whereas the deeper water is only connected with the outer ocean by the comparatively narrow entrance between New Providence and the north of Andros, leading, after a turn of about $90^{\circ}$, into the Providence N.E. and N.W. Channels.

The Laboratory from which this work was done was established at Golding Cay, at the eastern mouth of the South Bight of Andros; this position was especially suitable for the work, as by running out a few miles in a direction at right angles to the coast-line the middle of the Tongue of the Ocean could soon be reached, and also the mudflats to the west of the island were readily accessible by water, as the South Bight runs right through the island to the west coast. In this region the tides are not strong, the average rise and fall being from 2 to 3 feet. Much difficulty was experienced in getting any definite information as to the set of currents in the Tongue; our local pilot stated that a current would set in a southerly direction for weeks at a time, and then without any apparent reason or change of wind would reverse and set in a northerly direction for several weeks, but such information derived from the negro natives cannot be relied on. When taking observations on May 8th, May 11th, and May 23rd, we experienced a distinct southerly drift on each occasion, but the amount of this drift was not determined, and in addition the drift caused by the wind was an unknown factor. On May 8th the wind was S.S.E., of about force 1 at 8.30 a.m., freshening to about force 3 at 10.30 a.m.; a rough estimate from the landfall on returning gave the drift of the boat as about 2 miles south during the four hours occupied in working the station; the boat had a large awning and exposed a considerable area to the wind, and had drifted this distance against the wind, so it would seem that on that occasion there must have been a strong current setting south.

Andros Island consists of a limestone formation, the exact nature of which has been dealt with by Wayland Vaughan (17). The greater part of the island is very flat, and is only elevated a few feet above sea-level: a few irregular undulations, never more than 100 feet 
high, are found especially along the east coast. There is evidence to show that formerly the level of the land was much higher than at present, and signs of rapid erosion of the rock are everywhere obvious. One of the most remarkable features is the absence of soil even in the well-wooded parts of the island, the trees and bushes growing directly out of crevices and holes in the rock, and giving rise to practically no leaf mould. In the numerous "pot holes" which occur all over the island, a small deposit of black leaf mould can be found, and these "pot holes" are the favourite places for the cultivation of sugar-canes and bananas. The erosive action of water on the rock is especially noticeable where the slow drainage from an inland swamp can be traced in its course to the sea : in such a locality the hard rock is eroded, honeycombed, and undermined to a most remarkable degree, even though the amount of drainage, except after the heaviest rains, can scarcely be more than a slow trickle. Erosion of the rock along the sea-coast, where it is exposed to the action of the sea-spray, is also very marked. From the occurrence of this erosion it is obvious that all the water draining from the land into the sea must contain a high proportion of Calcium salts in solution.

Towards the west of the island the land is remarkably flat, and near the coast consists of white chalky mud, which has partially dried, and in places has formed a harder crust on the surface. These half-dried mud-flats slope almost imperceptibly into the sea, and are continuous with the submarine flats which extend some sixty miles off the west coast with an average depth of from two to three fathoms. The mud forming these submerged flats is very soft, and near the coast it was easily possible to push a twelve-foot sponge pole down to its full length into it without touching any harder material: the surface layer of the mud for a depth of about six inches is of a creamy white colour, but below that it is of a greyish tinge and has a slight odour of sulphuretted hydrogen. Unfortunately there was no opportunity of obtaining information as to the real thickness of this layer of mud, nor of investigating more than the surface layers at any distance from the coast.

Microscopical examination showed that this mud was almost entirely composed of minute unorganized particles of Calcium carbonate. Near the shore a good deal of organic matter, chiefly in the form of decaying mangrove roots, was present. Further out little organic matter was noticeable, but it was not possible to examine the deeper layers of the mud in these situations: the only organic matter that was seen consisted of the rootlets of a species of Zostera, which was found in occasional patches some miles off the coast. 


\section{BACTERIAL INVESTIGATIONS IN THE DEEP WATER IN THE TONGUE OF THE OCEAN.}

Continued bad weather during the whole of our stay at Andros greatly added to the difficulties of these investigations, and on this account it was only found possible to work three stations. The last two were worked under the most disadvantageous conditions, the quick roll of the boat making the filling of the water-bottle with Alcohol, and the syphoning off of the sample under sterile conditions, a matter of the greatest difficulty.

The first station worked was situated six miles due east of Golding Cay, the second 14 miles E. of Golding Cay, and the third 10 miles E.N.E. $\frac{1}{4}$ E. of Golding Cay. The three stations were thus situated at the angles of a triangle which was nearly equilateral, the base being a little longer than the sides, and running due east and west.

At the first station, worked on May 8th, bottom was sounded at 822 fathoms. The sea was calm at first, with a S.S.E. swell, but became choppy later. The wind was S.S.E., force 0 to 1 at 8.30 a.m., freshening to about force 3 at 10.30 a.m. The sample of the bottom obtained by the snapper rod was of a very stiff clay-like consistency, greyish white in colour, and was composed of very minute unorganized particles of Calcium carbonate, containing a few pteropod and globigerina shells. The following temperatures, to which the necessary corrections have been applied, were recorded:-

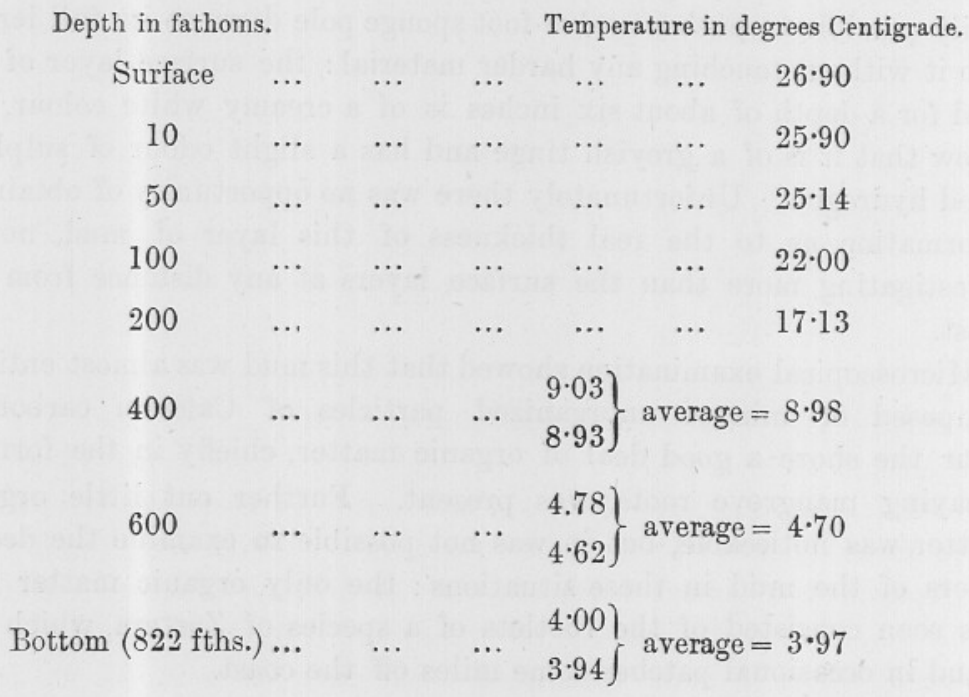


These samples, without previous dilution, were plated in Peptone Agar, 1 c.c. of the sample being used for each plate. The Agar was cooled to just under $40^{\circ} \mathrm{C}$. before plating. It is very necessary that this temperature should not be exceeded, as many marine bacteria are very sensitive to heat : the use of Agar at as high a temperature as $45^{\circ}$ C. will cause the death of a large proportion of the bacteria, though in the process of plating they can only be exposed to this temperature for a very short time. The cultures were kept in the dark at the room temperature (averaging about $28^{\circ} \mathrm{C}$.), and at the end of 24 hours a free growth of colonies was apparent. At the end of 48 hours the plates were counted with the following results :-

\section{Depth.}

Bottom

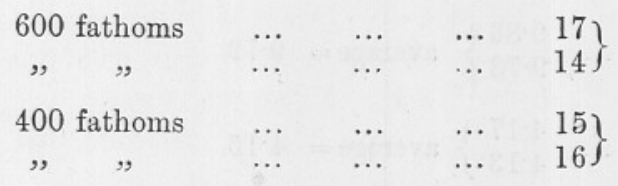

$\begin{array}{ccccc}200 \text { fathoms } & \ldots & \ldots & \ldots & 1760 \\ , " \quad, & \ldots & \ldots & \ldots & 1500\end{array}$

Very much overcrowded, indications of presence of many more colonies which have not developed owing to overcrowding.

100 fathoms $\quad \ldots \quad \ldots \quad \ldots \quad$ uncountable owing to overcrowding.

\begin{tabular}{|c|c|c|c|c|c|c|c|}
\hline , & $\cdots$ & $\cdots$ & $\cdots$ & , & , & , & , \\
\hline 50 fathoms & $\cdots$ & $\cdots$ & $\cdots$ & uncountable & , & , & , \\
\hline ," & $\cdots$ & $\cdots$ & $\cdots$ & , & و & , & , \\
\hline 10 fathoms & $\cdots$ & & $\cdots$ & uncountable & , & , & , \\
\hline , & $\cdots$ & $\cdots$ & $\cdots$ & , & , & , & " \\
\hline Surface $\quad \ldots$ & $\cdots$ & & & uncountable & , & פ' & ", \\
\hline$\cdots$ & $\cdots$ & $\cdots$ & $\cdots$ & , & , & , & , \\
\hline
\end{tabular}

From these counts it is apparent that the number of bacteria falls off at some point between 200 and 400 fathoms.

The second station was worked on May 11th, at a point 14 miles due east of Golding Cay. The sea was calm at first, and the wind E.N.E., force 1, but later in the day a heavy swell set in and the wind freshened to about force 4 ; eventually the weather became so bad that it was impossible to work, and the station had to be abandoned before it was completed. Bottom was sounded at 890

NEW SEries.-Vol. Ix. No. 4. MarCH, 1913. 
fathoms, but there was some stray on the wire, so that the true depth was probably about 825 fathoms, as shown by the chart. The bottom consisted of fine white calcareous ooze; no remains of pteropods were seen, but some globigerina shells were present. The following temperatures were recorded :-

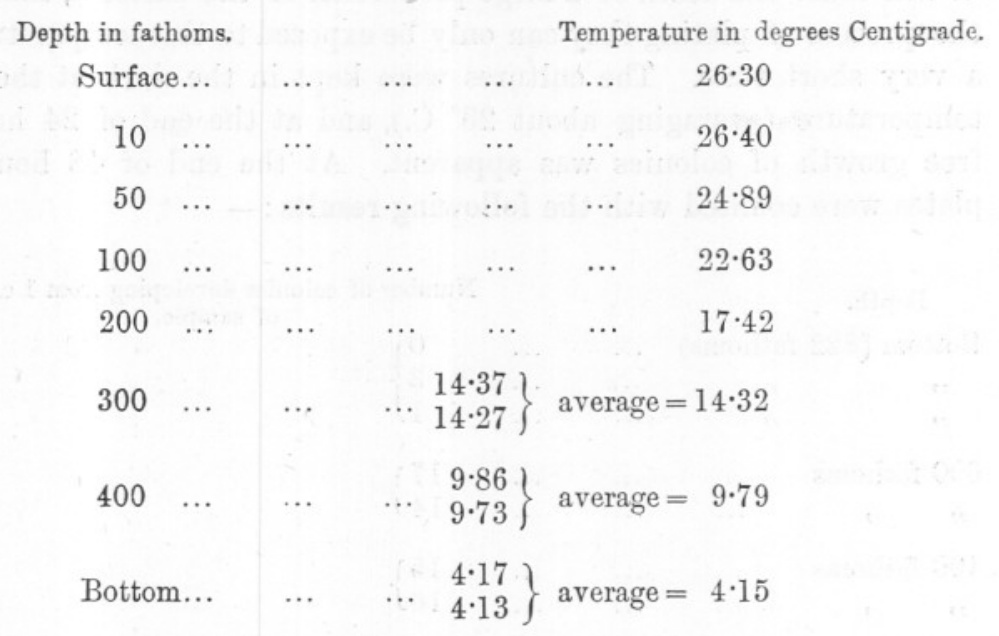

Samples down to a depth of 200 fathoms were diluted 1 in 100 with sterilized sea-water before plating. The following results were obtained after 48 hours' growth :-

$\begin{array}{rrrrrrr}\begin{array}{c}\text { Depth in fathoms. } \\ \text { Surface }\end{array} & \ldots & \ldots & \ldots & \ldots & \ldots & 16,200 \\ 10 & \ldots & \ldots & \ldots & \ldots & \ldots & 13,100 \\ 50 & \ldots & \ldots & \ldots & \ldots & \ldots & 14,000 \\ 100 & \ldots & \ldots & \ldots & \ldots & \ldots & 14,000 \\ 200 & \ldots & \ldots & \ldots & \ldots & \ldots & 15,000 \\ 300 & \ldots & \ldots & \ldots & \ldots & \ldots & 14 \\ 400 & \ldots & \ldots & \ldots & \ldots & \ldots & 12\end{array}$

The figures given represent the mean of the number of colonies developing in the two plates that were made from each sample. It is here apparent that the number of bacteria per 1 c.c. falls off very rapidly between 200 and 300 fathoms.

The third station was worked on May $23 \mathrm{rd}$ at a point 10 miles 
E.N.E. $\frac{1}{4}$ E. of Golding Cay. The wind was east, of about force 4 : as it had been blowing for the previous ten days without intermission, the sea was so rough that it was only possible to work when steaming slowly ahead into the wind. This resulted in the production of a great deal of stray on the sounding wire, so that the number of fathoms of wire run out is greater than the actual depth at which the samples were taken; these differences will be large for the more superficial samples, but small at greater depths, as the wire strays in a curve whose gradient becomes very steep a little below the surface, under these conditions.

The following temperatures were recorded :-

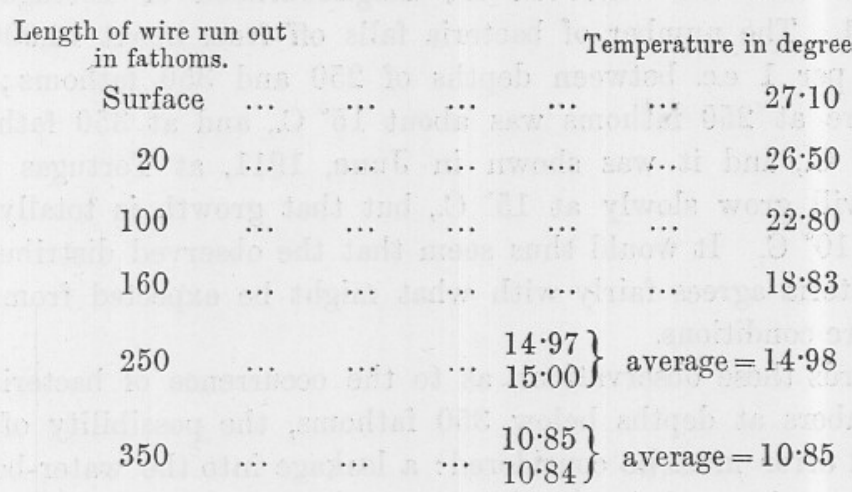

At this point the station had to be abandoned owing to the bad weather. The samples down to 160 fathoms were diluted 1 in 100 with sterilized sea-water before plating in Peptone Agar; the remaining two were plated undiluted. At the end of 48 hours the following counts were made:-

$\begin{array}{rrrrrrr}\begin{array}{c}\text { Length of wire run out } \\ \text { in fathoms. } \\ \text { Surface }\end{array} & \ldots & \ldots & \ldots & \ldots & \ldots & \begin{array}{c}\text { Number of colonies developing } \\ \text { from } 1 \text { c.c. of sample. }\end{array} \\ 20 & \ldots & \ldots & \ldots & \ldots & \ldots & 15,000 \\ 100 & \ldots & \ldots & \ldots & \ldots & \ldots & 13,700 \\ 160 & \ldots & \ldots & \ldots & \ldots & \ldots & 13,300 \\ 250 & \ldots & \ldots & \ldots & \ldots & \ldots & 14,300 \\ 350 & \ldots & \ldots & \ldots & \ldots & \ldots & 16\end{array}$

These numbers represent the mean of the number of colonies in the two plates made from each sample. 
The colonies developing in all the cultures were only of two kinds, the Bacterium calcis, and the non-denitrifying species already described. The non-denitrifying species formed a relatively small proportion of the total, and they were not found at all in cultures made from samples taken below 250 fathoms. As they appear to be comparatively chemically inactive, and as nothing is at present known concerning the part played by them in the metabolism of the sea, they will not be further considered here.

A consideration of these results obtained in the Tongue of the Ocean shows that the waters down to a depth of somewhere about 300 fathoms in April, 1912, contained an enormously larger number of bacteria than the water in the neighbourhood of Tortugas in June, 1911. The number of bacteria falls off from about 14,000 to about 12 per 1 c.c. between depths of 250 and 350 fathoms; the temperature at 250 fathoms was about $15^{\circ} \mathrm{C}$., and at 350 fathoms about $11^{\circ}$ C., and it was shown in June, 1911, at Tortugas that $B$. calcis will grow slowly at $15^{\circ} \mathrm{C}$., but that growth is totally inhibited at $10^{\circ} \mathrm{C}$. It would thus seem that the observed distribution of the bacteria agrees fairly with what might be expected from the temperature conditions.

As regards these observations as to the occurrence of bacteria in small numbers at depths below 350 fathoms, the possibility of experimental error must be considered: a leakage into the water-bottle of 0.25 c.c. as it was being hauled up through the last 300 fathoms would account for the number found, and there are also many possible sources of error in the process of siphoning off the sample, and making the cultures, where a permanent Laboratory is not available. It is possible that the water below 350 fathoms was really sterile, though if so the constancy of the results obtained is curious, if it is to be ascribed to experimental error. In any case, the small number of bacteria found at depths below 350 fathoms can play no part in the metabolism of the sea, since it has been shown that at the temperatures obtaining at these depths $B$. calcis is incapable of growth.

The much greater abundance of bacteria in the surface waters of the Tongue of the Ocean than in the waters round Tortugas may perhaps be accounted for by the fact that in the former locality by far the greater part of the surface water must flow over the immense chalky mud flats and shallows which bound it in most directions, and, as will presently be shown, these mud flats are phenomenally rich in bacteria, and are probably still being deposited by bacterial agency. 


\section{HYDROGRAPHIC OBSERVATIONS IN THE TONGUE OF THE OCEAN.}

The samples of water taken for hydrographic observations were analysed by Mr. D. J. Matthews at Plymouth. With great kindness he calculated the results, and from his notes the following observations and conclusions are drawn.

The samples were analysed for salinity in comparison with the standard sea-water supplied by the Central Laboratory of the Conseil International pour l'Exploration de la Mer, and hence the results are strictly comparable with all other analyses published under the auspices of this International Council.

At the first station, 6 miles east of Golding Cay, the following results were obtained :-

$\begin{array}{cccccc}\text { Depth in fathoms. Temperature. } & \mathrm{C} 1 \%{ }^{\circ} . & \mathrm{S} \%{ }^{\circ} & \sigma_{\circ} . & \sigma_{\mathrm{t}} \\ 0 & 26 \cdot 90 & 20 \cdot 06 & 36 \cdot 24 & 29 \cdot 12 & 23 \cdot 70 \\ 10 & 25 \cdot 90 & 20 \cdot 46 & 36 \cdot 96 & 29 \cdot 71 & 24 \cdot 57 \\ 50 & 25 \cdot 14 & 20 \cdot 43 & 36 \cdot 91 & 29 \cdot 66 & 24 \cdot 76 \\ 100 & 22 \cdot 00 & 20 \cdot 28 & 36 \cdot 64 & 29 \cdot 45 & 25 \cdot 48 \\ 200 & 17 \cdot 13 & 20 \cdot 08 & 36 \cdot 27 & 29 \cdot 15 & 26 \cdot 48 \\ 400 & 8.98 & 19 \cdot 58 & 35 \cdot 37 & 28 \cdot 43 & 27 \cdot 43 \\ 600 & 4 \cdot 70 & 19 \cdot 49 & 35 \cdot 21 & 28 \cdot 30 & 27 \cdot 90 \\ 822 & 3.97 & 19 \cdot 367 & 34 \cdot 98 & 28 \cdot 11 & 27 \cdot 79\end{array}$

Note.-The original surface sample was lost owing to breakage of the bottle in transit to England. The analysis was made on a sample taken three days later at the same spot.

In this table $\mathrm{C} 1 \%$ means the weight of Chlorine in grammes found in 1000 grammes of sea-water. S\% means the salinity, or the total weight of salt in grammes found in 1000 grammes of sea-water. $\sigma_{0}$ represents the specific gravity of the sample at $0^{\circ} \mathrm{C}$, and $\sigma_{t}$ represents the specific gravity of the sample at the temperature " $t$ " at which it was collected, with no correction for pressure.

At the second station, $13 \frac{1}{2}$ miles east of Golding Cay, the following results were obtained:- 


\begin{tabular}{rrrrrc} 
Depth in fathoms. & Temperature. & $\mathrm{C} 1 \%{ }^{\circ} \cdot$ & $\mathrm{S} \%{ }^{\circ}$ & $\sigma_{\circ}$. & $\sigma_{\mathrm{t}}$ \\
0 & $26 \cdot 30$ & $20 \cdot 25$ & 36.58 & $29 \cdot 40$ & $24 \cdot 15$ \\
10 & $26 \cdot 40$ & $20 \cdot 33$ & $36 \cdot 73$ & $29 \cdot 52$ & $24 \cdot 23$ \\
50 & $24 \cdot 89$ & $20 \cdot 395$ & $36 \cdot 84$ & $29 \cdot 61$ & $24 \cdot 78$ \\
100 & $22 \cdot 63$ & $20 \cdot 36$ & $36 \cdot 78$ & $29 \cdot 56$ & $25 \cdot 42$ \\
200 & 17.42 & $20 \cdot 12$ & $36 \cdot 35$ & $29 \cdot 21$ & $26 \cdot 47$ \\
300 & $14 \cdot 32$ & $19 \cdot 81$ & $35 \cdot 79$ & $28 \cdot 76$ & $26 \cdot 75$ \\
400 & $9 \cdot 79$ & $19 \cdot 56$ & $35 \cdot 34$ & $28 \cdot 40$ & $27 \cdot 27$ \\
890 & $4 \cdot 15$ & \multicolumn{2}{c}{ (No sample; bottle did not work.) }
\end{tabular}

Owing to the uncertainty of the depths at the third station, due to the bad weather and consequent stray on the wire, it was decided not to include these observations in a consideration of the hydrographic conditions, and to make what deductions were possible from the results obtained at the two stations given.

It is interesting to note that at the Challenger Station, No. 27, in $22^{\circ} 49^{\prime}$ N., $65^{\circ} 19^{\prime}$ W., March 28th, 1873, where the depth was 2960 fathoms, the actual temperature reading at 200 fathoms was $17 \cdot 22^{\circ} \mathrm{C}$., and that this agrees more closely with the temperatures in the Tongue of the Ocean than that taken from the Challenger smoothed curve, which was $18 \cdot 17^{\circ} \mathrm{C}$.

From this diagram it can be seen that the surface salinity increases from west to east very rapidly, $0.34 \%$ in $7 \frac{1}{2}$ miles, but the surface temperature is fairly uniform, between $26^{\circ} \mathrm{C}$. and $27^{\circ} \mathrm{C}$.

At both stations the salinity increases downwards to a maximum probably lying between 10 fathoms and 50 fathoms, but more rapidly at Station I, so that from 10 fathoms to 50 fathoms the salinity decreases from west to east.

Below 100 fathoms the conditions are closely similar at both stations, as far as the observations go; the salinity decreases fairly rapidly to 400 fathoms and then more slowly to the bottom.

The temperatures decrease rapidly and uniformly from the surface to about 500 fathoms, then more slowly to the bottom.

There is practically no thermocline (German sprungschicht) at any depth, and the salinity shows only a poorly marked discontinuity layer, confined to the upper stratum. This absence of a thermocline is remarkable.

In general; below about 250 fathoms the temperatures and salinities agree with the nearest stations of the Michael Sar's in the open Atlantic; 
above this depth they are higher, and differ from them and the open ocean, north of the belt of calms, in the absence of a temperature thermocline and in the maximum salinity being found below the surface. The latter points either to a considerable local supply of fresh water, or to a eurrent of lower salinity from either the Florida stream or the region of equatorial calms. Unfortunately we have no reliable salinity observations for the two latter.

The following section shows the vertical distribution of layers of different salinities and temperatures at the two stations in diagrammatic form :-

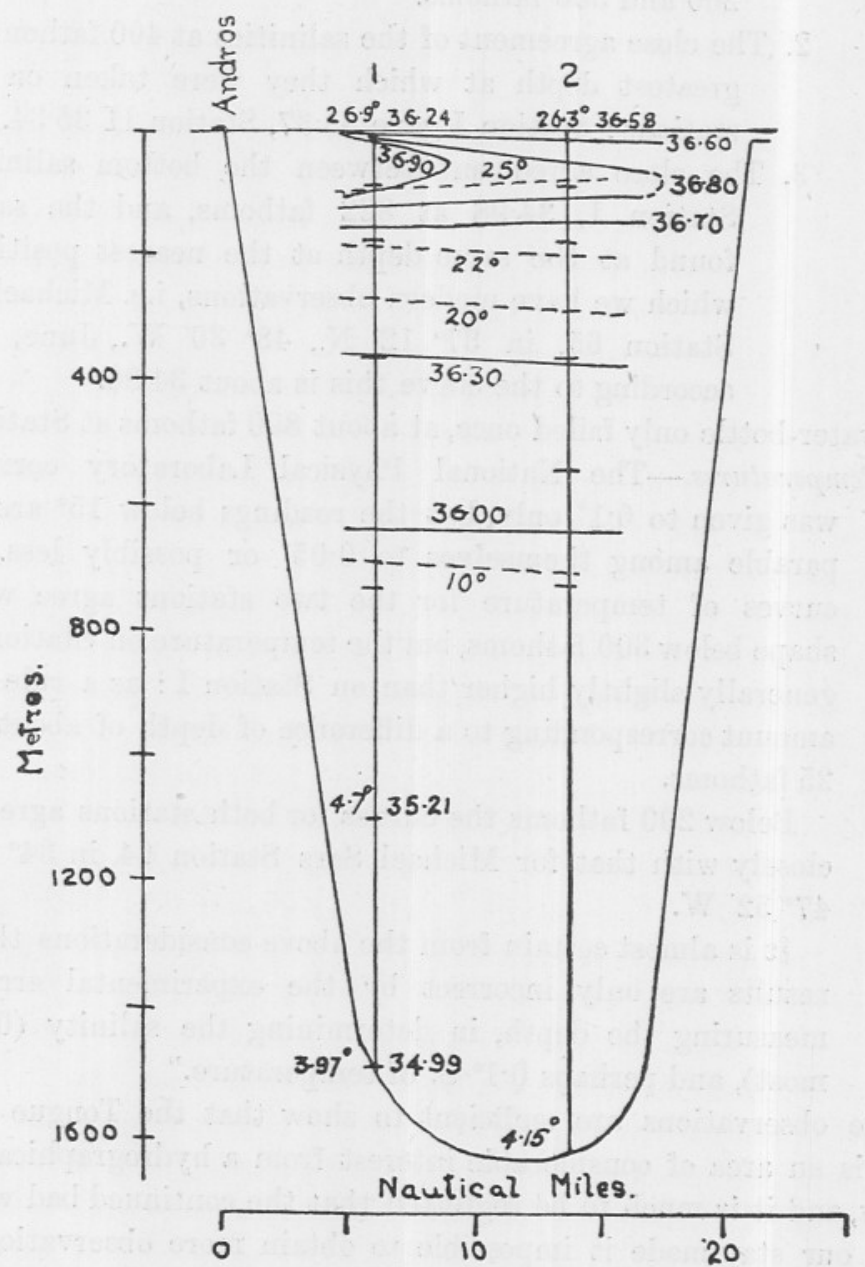

FIG. 2.-Section across the Tongue of the Ocean from Golding Cay, Andros Island eastwards. Broken lines $=$ isotherms, continuous lines $=$ isohalines. 
With regard to the accuracy of the work, Mr. Matthews makes the following remarks :-

"The accuracy of the observations.

(a) Salinity.-The method of taking the samples from the waterbottle was rather inconvenient, as a siphon was used; the samples were also very small, but well preserved. The water-bottle itself might have leaked or closed at the wrong depth, as was the case with earlier models. That this was not so is shown by:

1. The sharp fall in the number of bacteria at between 200 and 300 fathoms.

2. The close agreement of the salinities at 400 fathoms, the greatest depth at which they were taken on both stations: Station I gave $35 \cdot 37$, Station II $35 \cdot 34$.

3. The close agreement between the bottom salinity at Station I, 34.98 at 822 fathoms, and the salinity found at the same depth at the nearest position at which we have modern observations, i.e. Michael Sars, Station 65 , in $37^{\circ} 12^{\prime}$ N., $48^{\circ} 30^{\prime}$ W., June, 1910 : according to the curve this is about $34 \cdot 96$.

The water-bottle only failed once, at about 890 fathoms at Station II.

(b) Temperatures.-The National Physical Laboratory correction was given to $0.1^{\circ}$ only, but the readings below $15^{\circ}$ are comparable among themselves to $0.05^{\circ}$ or possibly less. The curves of temperature for the two stations agree well in shape below 300 fathoms, but the temperature on Station II is generally slightly higher than on Station I : as a rule by an amount corresponding to a difference of depth of about 20 to 25 fathoms.

Below 200 fathoms the curves for both stations agree very closely with that for Michael Sars Station 64, in $34^{\circ} 44^{\prime}$ N., $47^{\circ} 52^{\prime} \mathrm{W}$.

It is almost certain from the above considerations that the results are only incorrect by the experimental errors in measuring the depth, in determining the salinity $(0.02$ at most), and perhaps $0.1^{\circ} \mathrm{C}$. of temperature."

These observations are sufficient to show that the Tongue of the Ocean is an area of considerable interest from a hydrographical point of view, and it is much to be regretted that the continued bad weather during our stay made it impossible to obtain more observations and samples. 


\section{BACTERIAL INVESTIGATION OF THE CHALKY MUD- FLATS WHICH ARE BEING DEPOSITED TO THE WEST OF ANDROS ISLAND.}

Samples of the mud were taken from the western entrance of South Bight, and from points two and three miles out from the shore: practically identical results were obtained from all these localities. The sample at the mouth of the Bight was taken in about 4 feet of water, that two miles out in 7 feet, and that three miles out in 8 feet. The samples were necessarily taken from the surface of the mud.

For bacterial examination, one part of this mud was shaken up with three parts of sterilized sea-water; this was allowed to settle for 15 minutes, and then the clearer surface layer was diluted 1 in $1,000,000$ with sterilized sea-water. The diluted fluid was plated in Peptone Agar, 1 c.c. being used for each plate. The count of a number of plates after 48 hours gave 40 colonies as an average, and thus the surface mud itself must contain about $40 \times 4 \times 1,000,000$ $=160,000,000$ bacteria per 1 c.c. The actual number in the mud may exceed this figure, since a large proportion of the bacteria would possibly settle with the larger particles after the first dilution.

The bacteria found in these cultures were nearly all the B. calcis, only occasionally were a few colonies of the non-denitrifying species seen.

A sample of the water taken from the surface at a spot three miles out from the western entrance of South Bight gave a count of 35,000 colonies per 1 c.c., the great majority of these being $B$. calcis.

Subcultures of $B$. calcis were made in Gran's medium, and in the Calcium succinate, Calcium acetate, and Peptone Calcium acetate media, whose composition has already been given. Denitrification in all these media was rapid and eventually complete, and was accompanied by the precipitation of Calcium carbonate. In the last three media, which contained no solid matter and were quite clear and transparent before inoculation, this precipitation was manifested after twelve hours by the formation of a thick white cloud in the fluid, readily distinguishable from the cloudiness produced merely by bacterial growth. The development of this precipitate continued rapidly during the first forty-eight hours, but in many cases it was composed of such fine particles that they showed little tendency to settle to the bottom of the flask; in other cases larger particles were formed, and a sediment similar in appearance to the chalky mud of the mud-flats was produced. The exact conditions determining the size of the 
particles precipitated could not be ascertained, as the size varied largely in cultures made at the same time, in the same media, and kept apparently under the same conditions. The addition of Magnesium tartrate in small quantities $(0.2$ grammes per 1000 c.c. $)$ to the culture media seemed to induce the precipitation of larger particles, but it did not appreciably affect the rate of growth of the bacteria.

In some of the older cultures that had been kept for a week or more, the sides of the flasks were coated with a thin layer consisting of extremely minute rhombohedral crystals of Calcium carbonate. Occasionally these crystals formed around small bubbles that had remained near the surface of the fluid, the weight of the crystals eventually caused the bubbles to sink, and then the contained gas became dissolved; in this way a number of small hollow spheres were formed, their walls consisting of minute crystals of Calcium carbonate. The formation of these curious bodies occurred especially readily in the Calcium succinate medium to which 0.2 grammes of Magnesium tartrate per litre had been added. The deposition of Calcium carbonate in a distinctly crystalline form was only noted in old cultures, and then it was in an amount relatively extremely small when compared to the precipitate of apparently amorphous Calcium carbonate.

Specimens of the precipitates from some of the culture media were sent to Dr. Fred. E. Wright, of the Geophysical Laboratory of the Carnegie Institution, who with great kindness examined them, and described them as follows:-

"Preparation I. Precipitate from medium composed of-

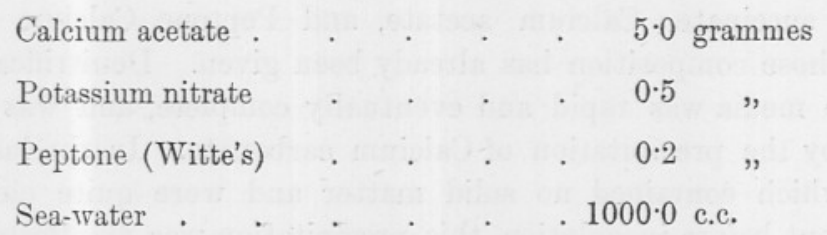

Filtered and sterilized.

"Contains two substances: (1) Fine grains of a strongly birefracting, apparently uniaxial, optically negative substance, and with refractive index about 1.66. This is probably calcite. The grains are isolated, and no evidence of spherulitic crystallization was observed. On treatment with very dilute Hydrochloric Acid, a noticeable evolution of Carbon dioxide took place. (2) Scattered through the preparation are 
fine needles of a weakly birefracting substance of about 1.525 refractive index; extinction angle large. These needles are evidently selenite (hydrated Calcium sulphate).

"Preparation II. Precipitate from medium composed of-

Calcium succinate

Magnesium tartrate

Potassium nitrate

Sea-water

\section{$2 \cdot 0$ grammes}

$0.2 \quad$,

$0.5 \quad$,

$1000 \cdot 0$ c.c.

"This preparation consists largely of a cryptocrystalline aggregate of a weakly birefracting substance, whose refractive index is about 1.52 to $1: 53$. This substance proved too fine for further determination. Scattered through this substance are rounded and irregular patches of a second cryptocrystalline substance of strong birefringence, which gives off $\mathrm{CO}_{2}$ when treated with dilute hydrochloric acid, and is probably calcite.

"Preparation III. Precipitate from a medium composed of-

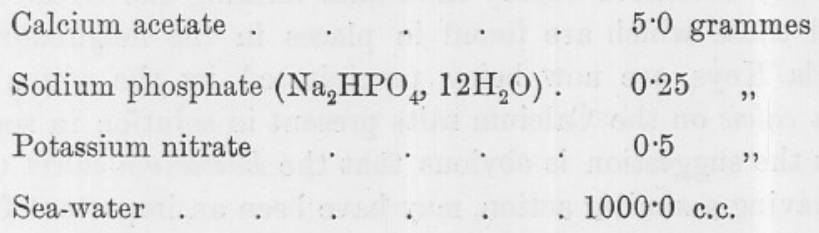

"This preparation is again very fine grained, and consists (1) in large measure of minute grains of a substance which agrees with calcite in its optical properties in so far as they could be determined. On immersion in dilute $\mathrm{HCl}$ a distinct evolution of $\mathrm{CO}_{2}$ gas was observed. (2) Of a substance whose grains are somewhat coarser than the calcite grains, their birefringence being medium to weak; refractive index about 1.525 ; biaxial and apparently optically positive; probably selenite, but not crystallized in the usual manner."

The small quantity of hydrated Calcium sulphate present in these precipitates is undoubtedly derived from that in solution in the seawater with which the media were made up, but the reason of its precipitation is difficult to explain since no such precipitation occurred in culture media kept uninoculated under similar conditions as control experiments. It would therefore appear that this deposition of CaIcium sulphate, along with the Calcium carbonate, must in some indirect way be the result of bacterial action, and it would seem a 
possible suggestion that the odour of sulphuretted hydrogen noticeable in the deeper layers of the mud-flats might be due to the reduction of the Calcium sulphate to a sulphide and subsequent decomposition of the sulphide by bacterial action.

These observations have shown that on the chalky mud-flats of the Great Bahama Bank the B. calcis is found in enormous numbers, and also that this bacterium is capable of precipitating Calcium carbonate from fluid media containing soluble Calcium salts. It would seem a fair deduction that these mud-flats have been precipitated by the action of the $B$. calcis on the soluble Calcium salts carried into the sea by drainage from the land, where extensive and rapid weathering of the limestone rock is in progress.

\section{CONCLUSION.}

The observations so far available are too few, and the area they cover too small, to attempt to make any broad generalization at present. However, it can be stated with a fair degree of certainty that the very extensive chalky mud-flats forming the Great Bahama Bank, and those which are found in places in the neighbourhood of the Florida Keys, are now being precipitated by the action of the Bacterium calcis on the Calcium salts present in solution in sea-water. From this the suggestion is obvious that the Bacterium calcis, or other bacteria having a similar action, may have been an important factor in the formation of various chalk strata, in addition to the part played by the shells of foraminifera and other organisms in the formation of these rocks. Dr. T. Wayland Vaughan has also suggested that the Miami oölite, and other oölitic rocks, may owe their origin to the occurrence of some diagenetic change in the precipitate of very finely divided particles of Calcium carbonate, produced in this way by bacterial action. If this view as to the formation of chalk and oölite rocks is correct, it would seem probable that these strata must have been deposited in comparatively shallow seas, whose temperature approximated to that of tropical seas at the present time.

It has also been shown that bacterial denitrification is far more rapid and complete in the tropical seas round Jamaica, the Dry Tortugas, and the Bahamas, than in the temperate waters of the Bay of Biscay and the English Channel, and hence an explanation is provided of the relative scarcity of plankton and algal growth in the former localities, in accordance with the terms of Brandt's (2) hypothesis. 
The distribution of the bacteria, both as to numbers and species, has been shown to vary at different localities and at different depths, but there are at present too few observations to enable any conclusions or generalizations to be drawn.

As it at present stands, the investigation can at most be considered to offer a mere indication of the part played by bacterial growth in the metabolism of the sea. To obtain a real insight into the question, it would be necessary to make more extensive bacterial and chemical observations in Tropical, Temperate, and Arctic waters, to study the bacteriology of other areas where Calcium carbonate is being precipitated from the sea, and to make further investigations in the Laboratory into the chemistry of the reactions that can be brought about by various species of marine bacteria.

\section{REFERENCES.}

1. BAUR, E. Ueber zwei denitrifizierende Bakterien aus der Ostsee. Wiss. Meeresunters. Kiel. VI. 1901.

2. Brandt, K. On the Production and the Conditions of Production in the Sea. Conseil Internat. Rapp. et Proc. Verb. III. 1905.

3. Brandt, K. Ueber die Bedeutung der Stickstoffverbindungen für die Produktion im Meere. Botan. Centralblatt. XVI. 1904.

4. Drew, G. Harold. Report of Preliminary Investigations on the Marine Denitrifying Bacteria. Year Book No. 10 of the Carnegie Institution of Washington. 1911.

5. Drew, G. Harold. The Action of some Denitrifying Bacteria in Tropical and Temperate Seas, and the Bacterial Precipitation of Calcium carbonate in the Sea. Jour. of the Marine Biolog. Assoc. of the U.K. Vol. IX., No. 2. 1911.

6. Drew, G. Harold. Report of Investigations on Marine Bacteria carried on at Andros Island, Bahamas, B.W.I., in April, 1912. Year Book No. 11 of the Carnegie Institution of Washington. 1912.

7. Feitel, R. Beiträge zur Kenntnis denitrifizierender Meeresbakterien. Wiss. Meeresunters. Kiel. VII. 1903.

8. Fischer, B. Die Bakterien des Meeres. German Plankton Expedition, 1894.

9. Gran, H. H. Studien über Meeresbakterien I. Bergens Museums Aarbog No. 10. 1901.

10. Keding, M. Weitere Untersuchungen über stickstoffbindende Bakterien. Wiss. Meeresunters. Kiel. IX. 1906.

11. Keutner, J. Über das Vorkommen und Verbreitung Stickstoffbindender Bakterien im Meere. Wiss. Meeresunters. Kiel. VIII. 1905.

12. Matthews, D. J. A Deep-sea Bacteriological Water-bottle. Journ. Mar. Biol. Assoc. of the U.K., Vol. IX, No. 4. 1913.

13. Murray, Sir John, and HJort, J. The Depths of the Ocean. London, 1912. 
14. Murray, J., and Irvine, R. On Coral Reefs, and other Carbonate of Lime Formations in Modern Seas. Proc. Royal Soc. of Edinburgh. Vol. XVII. 1889.

15. RABEN, E. Über quantitative Bestimmung von Stickstoffverbindungen im Meerwasser. Wiss. Meeresunters. Kiel, VIII. 1905.

16. Thомsen, P. Über das Vorkommen von Nitrobakterien in Meere. Wiss. Meeresunters. Kiel. XI. 1910.

17. VAUGHan, T. WAyland. Report in Year Book No. 12 of the Carnegie Institution of Washington, 1913. 